\title{
Sources evaluation and ecological risk assessment of heavy metals accumulated within a natural stream of Durgapur industrial zone, India, by using multivariate analysis and pollution indices
}

\author{
K. K. Pobi ${ }^{1}$ S. Satpati ${ }^{2}$ S. Dutta ${ }^{1}$ S. Nayek ${ }^{3,4} \cdot$ R. N. Saha ${ }^{1} \cdot$ S. Gupta ${ }^{5}$ \\ Received: 19 November 2016 / Accepted: 21 March 2019 / Published online: 27 March 2019 \\ (C) The Author(s) 2019
}

\begin{abstract}
In this study, variations in physicochemical parameters and heavy metal contamination in water-sediments of a natural stream in the Durgapur industrial zone have been investigated. $\mathrm{pH}, \mathrm{COD}, \mathrm{Cl}^{-}, \mathrm{CN}^{-}$and heavy metals, viz. $\mathrm{Pb}, \mathrm{Hg}$ and $\mathrm{Fe}$ concentrations in channel water, are higher than Indian standards. Metal concentrations in sediments are many folds higher than background value, where $\mathrm{Pb}, \mathrm{Cd}, \mathrm{Hg}$ and $\mathrm{Cr}$ contents exceed the sediment quality guidelines. Contamination factor $\left(C_{\mathrm{f}}\right)$ value of channel water follows the order of $\mathrm{Hg}>\mathrm{Pb}>\mathrm{Fe}>\mathrm{Cr}>\mathrm{Cd}>\mathrm{Cu}>\mathrm{Ni}$, whereas enrichment factor and geoaccumulation index $\left(I_{\text {geo }}\right)$ values in channel sediments are in the order of $\mathrm{Hg}>\mathrm{Cr}>\mathrm{Ni}>\mathrm{Pb}>\mathrm{Cd}>\mathrm{Fe}>\mathrm{Cu}$. The assessment of contamination index $\left(C_{\mathrm{d}}\right)$, modified contamination index $\left(\mathrm{mC}_{\mathrm{d}}\right)$ and pollution load index indicates that channel water and sediment samples in the study area are strongly contaminated by heavy metals. Sediment samples based on PELQ and ERMQ are highly toxic, with high degree of potential ecological risk at all the monitored stations. Multivariate analysis infers that heavy metals in channel water and sediments are majorly sourced from industrial discharge.
\end{abstract}

Keywords Physicochemical characterization $\cdot$ Heavy metals $\cdot$ Seasonal variation $\cdot$ Pollution indices $\cdot$ Risk assessment . Multivariate analysis

\section{Introduction}

Heavy metal contamination in surface water and sediments due to industrial discharge is an issue of major environmental concern in a fast-growing country like India and has attracted the considerable attention of scientific and regulatory communities due to the persistence and toxicity of

\section{R. N. Saha}

rajusaharupa@yahoo.com

1 Department of Chemistry, National Institute of Technology, Durgapur, West Bengal, India

2 National Power Training Institute (Eastern Region), Durgapur, West Bengal, India

3 School of Basic and Applied Sciences, RNB Global University, Bikaner, Rajasthan, India

4 Present Address: Department of Environmental Science, Amity Institute of Applied Sciences, Amity University, Kolkata, West Bengal, India

5 Department of Environmental Science, The University of Burdwan, Bardhaman, West Bengal, India heavy metals in the aquatic system. Indiscriminate discharge of untreated sewage, industrial waste and other anthropogenic activities caused a significant deterioration in water and sediment quality, especially near large industrial complexes and in the lower basin (Kumar and Maiti 2015; Chung et al. 2016). In recent times, considerable research has been conducted to investigate heavy metal contamination in water and sediments of rivers/natural streams in industrially polluted various regions in India. Banerjee et al. (2016) investigated the seasonal variations in heavy metal concentrations in water sediments of Subarnarekha river due to the discharge of industrial and mining waste near Jamshedpur industrial region, eastern India. Sundaray et al. (2012) studied the dissolved heavy metal load and their seasonal variations in the Mahanadi river sourced from fertilizer plants and municipal sewage. Heavy metal contamination due to industrial and urban discharge in water-sediment system of Hindon river and Yamuna river near to the industrial regions of Haryana and Delhi (in northern India) was reported by Suthar et al. (2009) and Kaushik et al. (2009), respectively. Heavy metal contamination in water sediments of Kabini river and heavy metal accumulation in sediments of Cauvery 
river due to industrial and urban discharge in Karnataka (southern India) were reported by Hejabi et al. (2011) and Raju et al. (2012), respectively. Shah et al. (2012) assessed heavy metal contamination in the sediments of Tapti river near Hazira industrial zone, Surat (western India). The concentrations of heavy metals in water, sediments and wetland plants of the lentic water body in Singrauli industrial region and Mangalpur industrial complex were reported by Rai (2009) and Gupta et al. (2008, 2010a), respectively. Industrial effluents and wastes dumped into water bodies alter its physicochemical characteristics and elevate the heavy metal concentration according to the nature of effluent being discharged (Blinova et al. 2012). Besides chemical leaching from bedrock, water drainage basin and runoff from banks are the leading sources for the lithogenic contribution of heavy metals (Jain et al. 2005; Shakeri et al. 2016). Heavy metals added to the aquatic system are distributed during their transport between the aqueous phase and bed sediments (Sin et al. 2001). The measurements of pollutants in water are not conclusive due to fluctuation in water discharge and low residence time. The study of sediments is important as they have a long residence time, receive and absorb pollutants and have been recognized as secondary sources of water pollution (Jain et al. 2005; Liu et al. 2009). Therefore, analysis of bed sediment is a powerful approach not only for studying the distribution of contaminants in an aquatic system, but also for reconstructing historical inputs of these contaminants, improving management strategies and evaluating the effectiveness of recent pollution control measures (Lara-Martín et al. 2015).

\section{Description of the study area}

The field study was conducted along a natural stream near Durgapur industrial complex, one of the most industrialized cities in eastern India, located at $23.48^{\circ} \mathrm{N} 87.32^{\circ} \mathrm{E}$ (Fig. 1a). The study area belongs to the tropical climatic condition with two distinct seasons-dry (summer and winter) and rainy (during monsoon) with an annual rainfall of 52". Geologically, the study area is overlain by hard crust laterite of Cenozoic age (Fig. 1b). Within the laterites, Panchet formation and Durgapur bed of Gondwana supergroup are exposed. The eastern and southern part of the study area have moderate to very hard rock types of red shale, sandstone and very coarse sandstone, respectively. The southern part of the study area, along the Damodar river, is mostly dominated by clay alternating with silt and sand of Panskura formation (Quaternary) having the characteristics of soft, unconsolidated sediments (oxidized).

Studied natural stream (locally known as Tamla Nala) is a narrow channel fed by rain water and surface runoff, having an average elevation of $65 \mathrm{~m}(213 \mathrm{ft})$, with a flow rate of $13.33 \pm 0.5$ to $14.7 \pm 0.15 \mathrm{ml} / \mathrm{s}$. A major portion of its course (about $17 \mathrm{~km}$ ), especially middle and downstream stretch, passes through the Durgapur industrial zone and ultimately terminates into the river Damodar near Majher Mana. This channel serves mainly as stormwater drainage for Durgapur industrial zone. The upstream stretch of the channel is devoid of industrial and anthropogenic discharges, but the middle section and downstream stretch of the channel are heavily affected by the industrial effluents and waste discharges. Besides, additions of domestic/urban wastewater, atmospheric deposition of heavy metals and surface runoff from adjoining areas, mainly during the rainy season, are the supplementary contributors of pollutant load in channel water. Our field study is focused on middle to downstream stretches of this natural stream (approximately $10 \mathrm{~km}$ ) which is heavily contaminated by industrial and urban wastewater discharges. A number of heavy industries (including iron \& steel, coal-based thermal power plants, cement, chlor-alkali, pharmaceuticals, fertilizers) as well as clusters of mediumand small-scale auxiliary industries of Durgapur industrial belt draining their wastewater enriched with heavy metals into the Tamla stream leading to heavy metal contamination in water-soil system and existing biota (Kisku et al. 2011). Barman and Lal (1994) and Barman et al. (2000) studied heavy metal accumulation and distribution in agricultural soil-cultivated vegetables and weeds grown in industrially polluted fields in Durgapur region. Contamination of soil and plants with potentially toxic elements irrigated with mixed industrial effluents was reported by Kisku et al. (2000). Gupta et al. (2010b, 2013) assessed biochemical changes in wastewater-irrigated vegetables and also the distribution of pollutants in stream water. But no such in-depth information is available on heavy metal contamination/distribution in channel sediments and its potential ecological risk. This research aims to focus on (1) spatial and seasonal variability of water parameters and heavy metals in channel water, (2) ecological risk assessment of metal contamination in channel water and sediments and (3) multivariate analysis to identify possible sources of contamination and the relative contribution of various water parameters.

\section{Materials and methodology}

\section{Water samples collection and analysis}

Water samples were collected from eight (8) different sampling sites at regular intervals started from the middle to downstream stretches of the stream (Fig. 1a), and the brief description of sampling stations is given in Table 1. Water samples were collected in wide mouth pre-acid-washed polythene bottles and rinsed with sample water before fill-up to the capacity (1 l). Water $\mathrm{pH}$, temperature, conductivity (EC) and total dissolved solids (TDS) were measured at the 

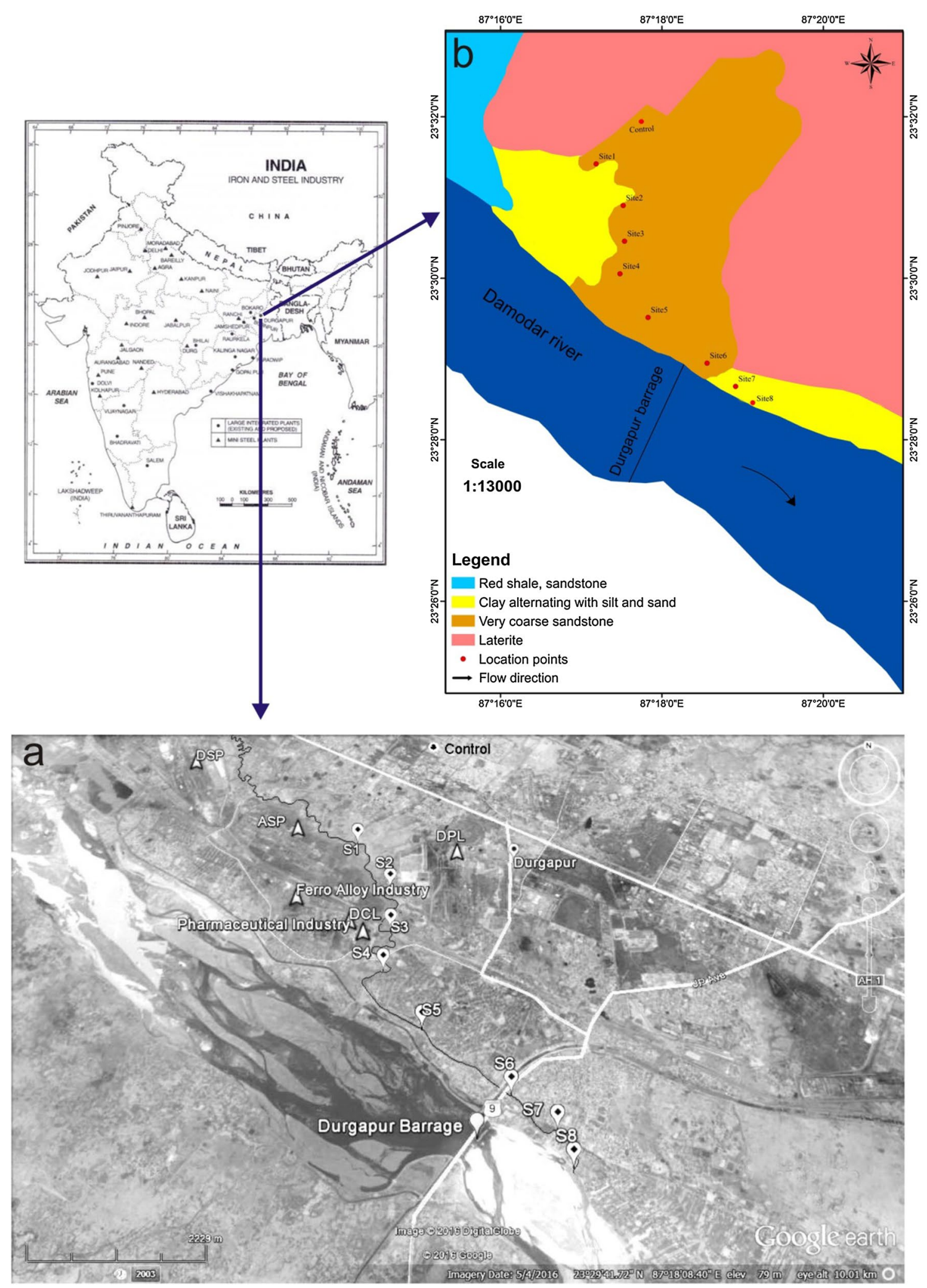

Fig. 1 Location of sampling sites (a) and regional geology (b) of the study area 
Table 1 Description of the sampling sites

\begin{tabular}{llll}
\hline $\begin{array}{l}\text { Sam- } \\
\text { pling } \\
\text { station }\end{array}$ & Latitude & Longitude & Description of the sampling location \\
\hline S1 & $23^{\circ} 31^{\prime} 25.02^{\prime \prime} \mathrm{N}$ & $87^{\circ} 17^{\prime} 11.11^{\prime \prime} \mathrm{E}$ & About 4 km away from the discharge point after two major steel and alloy industries (DSP and ASP) \\
S2 & $23^{\circ} 30^{\prime} 54.13^{\prime \prime} \mathrm{N}$ & $87^{\circ} 17^{\prime} 31.19^{\prime \prime} \mathrm{E}$ & Located after coke-oven industries \\
S3 & $23^{\circ} 30^{\prime} 27.61^{\prime \prime} \mathrm{N}$ & $87^{\circ} 17^{\prime} 32.21^{\prime \prime} \mathrm{E}$ & Located near thermal power plant, ferro-alloy and chlor-alkali industries \\
S4 & $23^{\circ} 30^{\prime} 3.42^{\prime \prime} \mathrm{N}$ & $87^{\circ} 17^{\prime} 28.81^{\prime \prime} \mathrm{E}$ & Site is near to pharmaceutical industry and DCL residential complex \\
S5 & $23^{\circ} 29^{\prime} 31.00^{\prime \prime} \mathrm{N}$ & $87^{\circ} 17^{\prime} 49.71^{\prime \prime} \mathrm{E}$ & Site is not affected by the any kind anthropogenic activity or discharge from industries, residential \\
& & & or agricultural units \\
S6 & $23^{\circ} 28^{\prime} 57.03^{\prime \prime} \mathrm{N}$ & $87^{\circ} 18^{\prime} 33.63^{\prime \prime} \mathrm{E}$ & Located near Birbhanpur village and down-part of DPL colony \\
S7 & $23^{\circ} 28^{\prime} 39.75^{\prime \prime} \mathrm{N}$ & $87^{\circ} 18^{\prime} 54.84^{\prime \prime} \mathrm{E}$ & Located near Shyampur village and agricultural fields \\
S8 & $23^{\circ} 28^{\prime} 22.63^{\prime \prime} \mathrm{N}$ & $87^{\circ} 19^{\prime} 0.88^{\prime \prime} \mathrm{E}$ & Site is located at the river side before the termination of studied stream to river Damodar \\
\hline
\end{tabular}

sites by using portable hand analyzer (Multi-Parameter PCS TestrTM 35, Oakton). For estimation of heavy metals, water samples were fixed with $0.5 \mathrm{ml}$ of conc. $\mathrm{HNO}_{3}$ immediately after the collection to prevent precipitation of metals. Samples were taken to the laboratory and stored in the ice box for further analysis of various water parameters. Physicochemical analysis of water parameters was performed as per standard methods for the examination of water and wastewater (Lenore et al. 1998). For heavy metal analysis, water samples were digested with 3:1 (v/v) mixture of concentrated $\mathrm{HNO}_{3}$ and $\mathrm{HClO}_{4}$ (Lenore et al. 1998). Digested water samples were filtered with Whatman No. 42 filter paper and filtrate analyzed for lead $(\mathrm{Pb})$, cadmium $(\mathrm{Cd})$, chromium $(\mathrm{Cr})$, iron $(\mathrm{Fe})$, copper $(\mathrm{Cu})$ and nickel $(\mathrm{Ni})$ in atomic absorption spectrophotometer (GBC, Avanta), and Mercury (Hg) was estimated by cold vapor atomic absorption.

\section{Analysis of sediment samples from the channel}

Sediment samples were collected from the same location (eight sampling sites) from where the water samples were collected. Surface sediment samples were collected from 0 to $5 \mathrm{~cm}$ depth of the channel by using a stainless steel hand digger and were immediately kept in airtight zipped plastic bags. In laboratory conditions, sediment samples were airdried, crushed with a pestle in a mortar and sieved through 2-mm mesh for physicochemical characterization. Homogenized sediment samples were analyzed for $\mathrm{pH}$ and electrical conductivity (EC) as per standard methods (Lenore et al. 1998). Total organic matter (OM) and organic carbon (OC) of sediments were determined as stated by Walkley and Black (1934). For estimation of heavy metal concentrations, $1 \mathrm{~g}$ of air-dried homogenized sediment samples was digested with a mixture of concentrated $\mathrm{HNO}_{3}$ and $\mathrm{HClO}_{4}$ (3:1) (USEPA, Method 3051A, 2007). The solution was filtered, diluted to $50 \mathrm{ml}$ with ultrapure water and analyzed for $\mathrm{Pb}, \mathrm{Cd}, \mathrm{Cr}, \mathrm{Fe}, \mathrm{Cu}$ and $\mathrm{Ni}$ contents in atomic absorption spectrophotometer (AAS). Hg was estimated by cold vapor atomic absorption. As there were no previously recorded background values for metal content in sediments before the industries were set up, a set of sediment samples were collected near the upper reaches of the stream (about $2 \mathrm{~km}$ away from the contaminated site) which is devoid of any type of industrial, urban, agricultural discharges which under the similar lithological units were considered as background or control sample value.

\section{Quality control and assurance}

Special care has been taken during sample collection, preservation and every experimental procedure. E-Mark (AR grade) standard solutions were used for the preparation of standard curve and intermediate solutions during the analysis of heavy metals and other physicochemical parameters of water and sediment samples. Ultrapure water (resistivity $=18.2 \mathrm{M} \Omega / \mathrm{cm}$ ) (Sartorius stedim biotech, arium ${ }^{\circledR} 61316$ ) was used for the preparation of all the solution. The element standard solutions used for calibration were prepared by diluting stock solutions (Merck AA standard) of $1000 \mathrm{mg} / \mathrm{l}$ using micropipette. All glassware was cleaned by soaking in dilute acid for at least $24 \mathrm{~h}$ and rinsed properly in ultrapure water before use. Each analytical process (related to water and sediment analysis) was replicated three times to ensure the accuracy of the experimental results, and mean values were used. The analytical results for heavy metals in water and sediment samples were checked by using the standard reference material from National material testing laboratory, India. Reproducibility of analytical results was within 5\% standard error (SE) level of certified values for each metal.

\section{Different pollution indices for assessing metal contamination in water and sediments}

Pollution indices seem to be promising and beneficial in assessing the metal enrichment and/or contamination in the water-sediment system. There are several methods to 
assess water sediment quality and describe the contamination adverse effects (Ridgway and Shimmield 2002). Heavy metal contamination in channel water and sediments was evaluated by using contamination factor $\left(C_{\mathrm{f}}\right)$, degree of contamination $\left(C_{\mathrm{d}}\right)$, and modified degree of contamination $\left(\mathrm{mC}_{\mathrm{d}}\right)$, enrichment factor $(\mathrm{EF})$, geo-accumulation index $\left(I_{\text {geo }}\right)$ and pollution load index (PLI).

The contamination factor $\left(C_{\mathrm{f}}\right)$ (Hakanson 1980 , Backman et al. 1997) is the ratio obtained by dividing the concentration of each metal in the water/sediment by upper permissible value or its background value (concentration in uncontaminated water/sediment):

$C_{\mathrm{fi}}=\frac{\text { Analytical value for ith component }}{\text { Permissible limit for ith component }}$.

$C_{\mathrm{f}}$ values were interpreted (Hakanson 1980) as: $C_{\mathrm{f}}<1=$ low contamination; $1<C_{\mathrm{f}}<3=$ moderate contamination; $3<C_{\mathrm{f}}<6=$ considerable contamination and $C_{\mathrm{f}}>6=$ very high contamination.

Contamination index $\left(C_{\mathrm{d}}\right)$ was used to measure the quality of water and wastewater (Backman et al. 1997). The contamination index is calculated from the equation below

$C_{\mathrm{d}}=\sum_{i=1}^{n} C_{\mathrm{f}}^{\mathrm{i}}$

where $C_{\mathrm{f}}^{\mathrm{i}}$ are the individual contamination factors for the selected element and $\mathrm{n}$ is the number of the $\mathrm{C}_{\mathrm{f}} \mathrm{s}$ examined for specific element. The $\left(C_{\mathrm{d}}\right)$ is computed separately for each sampling site as a sum of contamination factors $\left(C_{\mathrm{f}}\right)$ of individual elements exceeding the permissible limits. Backman et al. (1997) described the degree of contamination $\left(C_{\mathrm{d}}\right.$ value $)$ as: $C_{\mathrm{d}}<1=$ low $\left(1<C_{\mathrm{d}}<3=\right.$ medium, and $\left(C_{\mathrm{d}}>3=\right.$ high.

Abrahim and Parker (2008) presented a modified form of the Hakanson (1980) equation for the calculation of the overall degree of contamination using following equation:

$\mathrm{mC}_{\mathrm{d}}=\frac{\sum_{i=1}^{n} C_{\mathrm{f}}^{\mathrm{i}}}{n}$,

where $n$ is the number of analyzed elements, $i$ is the element, and $C_{\mathrm{f}}$ is the contamination factor. Gradation of sediment quality (Abrahim and Parker 2008), according to the calculation of $\mathrm{mC}_{\mathrm{d}}$ values was categorized as: $\mathrm{mC}_{\mathrm{d}}$ value $1.5-2=$ low contamination, $2<\mathrm{mC}_{\mathrm{d}}<4=$ moderate contamination, $4<\mathrm{mC}_{\mathrm{d}}<8=$ high contamination, $8<\mathrm{mC}_{\mathrm{d}}<16=$ very high contamination and $\mathrm{mC}_{\mathrm{d}}>16=$ extremely high degree of contamination.

To evaluate natural or anthropogenic sources of heavy metals in sediment, the enrichment factor (EF) is calculated for sediment samples using conservative elements such as Al, Fe, Sc and Ti (Lee et al. 1998; Abrahim and Parker 2008) as reference elements.

The reference values were adopted from the baseline concentration of heavy metals using following equation:

$\mathrm{EF}=\frac{[M] /[\mathrm{Fe}]_{\text {sediment }}}{[M] /[\mathrm{Fe}]_{\text {baseline }}}$

where $[M]=$ total heavy metals concentrations measured in sediment samples $(\mathrm{mg} / \mathrm{kg})$ and $[\mathrm{Fe}]=$ total concentration of iron as the reference element $(\mathrm{mg} / \mathrm{kg})$. Five categories are recognized on the basis of enrichment factor (Sutherland 2000; Loska and Wiechuya 2003). EF value $<1-2=$ deficiency to minimal enrichment, $2<\mathrm{EF}<5=$ moderate enrichment, $5<\mathrm{EF}<20=$ significant enrichment, $20<\mathrm{EF}<40=$ very high enrichment, and EF $>40=$ extremely high enrichment.

Muller (1981) introduced the index of geo-accumulation $\left(I_{\text {geo }}\right)$ which enables the assessment of metal accumulation in bottom sediments by comparing present and pre-industrial concentration.

$I_{\text {geo }}=\log _{2} \frac{M_{\mathrm{x}}^{\mathrm{i}}}{1.5 M_{\mathrm{b}}^{\mathrm{i}}}$,

where $M_{\mathrm{x}}$ is the measured metal concentrations in sediment fraction $(<2 \mu \mathrm{m})$ and $M_{\mathrm{b}}$ is the geochemical background value of metals. The factor 1.5 is introduced to include possible variations of background value due to natural fluctuations. Geo-accumulation index is classified as: $I_{\text {geo }}$ value $<1=$ uncontaminated or no pollution, $1<I_{\text {geo }}<2=$ slightly polluted, $2<I_{\text {geo }}<3=$ moderately polluted, $3<I_{\text {geo }}<4=$ strongly or highly polluted and $I_{\text {geo }}>4=$ extremely polluted (Muller 1981).

Pollution load index (PLI) provides a simple, comparative means for assessing soil/sediment quality (Tomlison et al. 1980). PLI is represented as geometric mean of $C_{\mathrm{f}}$ value of $n$ number of metals estimated at the contaminated site by using the following equation:

$\mathrm{PLI}=\left(C_{\mathrm{f}_{1}} \times C_{\mathrm{f}_{2}} \times \cdots \times \mathrm{C}_{\mathrm{f}_{n}}\right)^{1 / n}$

where $n$ is the number of metals ( $n=7$ in this study) and $C_{\mathrm{f}}$ is the contamination factor $\left(C_{\mathrm{f}}\right)$ of each metal present in the sediment. PLI $\leq 0$ indicates perfection or control and PLI value of $>0-1$ represents the baseline level of pollutants, while PLI $>1$ indicates progressive deterioration of site due to elevated metal content (Gupta et al. 2013).

\section{Statistical analysis}

Pearson's correlations are performed between water quality parameters and also for various sediment parameters for 
analyzing the interrelations between them. Factor analysis is used as a numerical method for discussing variables and identifying geochemical processes by extracting minimum acceptable eigenvalue $>1$. Principle component analysis (PCA) along with varimax rotation is performed for physicochemical parameters of channel water and sediment samples to analyze the interrelated variations and also to identify their possible sources. Pearson's correlations $(r)$ are performed between the physicochemical parameters and heavy metals in stream water and sediments for the better interpretation and understanding of metal distribution and their interrelations in water-sediment system. Statistical calculations are carried out at significance level 0.05 by XLSTAT (version 15.1).

\section{Results and discussion}

\section{Characterization and spatial variation of physicochemical parameters in stream water}

The physicochemical characteristics of channel water samples from eight sites are summarized (Table 2) and compared with the Indian Standards for effluent discharged to inland surface waters (IS 1981). The $\mathrm{pH}$ of channel water is highly alkaline with highest value at Site $3(\mathrm{pH} 10.22 \pm 1.20)$ and then gradually decreases until it reaches the lowest value of $8.83 \pm 1.03$ at Site 8 . Water $\mathrm{pH}$ values at all the sites (except Site 8) are higher than the IS discharge standards. Total dissolved solid (TDS) gives a better idea about the solid load transported by the channel water, which mainly consists of a variety of inorganic minerals including different salts (Rai 2010). TDS value in water is under the IS permissible limits, but its higher value is noted at Site 3,4 and 7. Total hardness $(\mathrm{TH})$ is well under the permissible limit at all sites with a maximum value at Site $3(65.56 \pm 17.09 \mathrm{mg} / \mathrm{l})$. Chemical oxygen demand (COD) is an indicator of chemical pollutants in the aquatic system. COD values at all the sampling sites exceed the IS standard $(250 \mathrm{mg} / \mathrm{l})$ with a maximum value at Site $3(466.8 \pm 97.80 \mathrm{mg} / \mathrm{l})$ and minimum at Site 8 $(415.42 \pm 62.89 \mathrm{mg} / \mathrm{l})$ showing a decreasing trend. A slight increase in COD value at Site $7(430.94 \pm 59.29 \mathrm{mg} / \mathrm{l})$ can be attributed to the mixing of sewage water at this point. However, evaluation of biological oxygen demand (BOD) at all sampling points shows low values (maximum value $27.73 \pm 5.62 \mathrm{mg} / \mathrm{l}$ at Site 7 ) and is well below the permissible limit. The BOD and COD ratios for the stream water samples are very low $(0.04-0.1)$. This signifies poor availability of biodegradable organic compounds and greater loading of non-biodegradable waste, and thus higher recalcitrant of pollutant in stream water and sediments (Adams et al. 1997). The mean chloride $\left(\mathrm{Cl}^{-}\right)$concentrations in channel

Table 2 Spatial characteristics of physicochemical parameters and heavy metal concentrations in stream water samples

\begin{tabular}{|c|c|c|c|c|c|c|c|c|c|}
\hline Parameters & Site 1 & Site 2 & Site 3 & Site 4 & Site 5 & Site 6 & Site 7 & Site 8 & IS standard \\
\hline $\mathrm{pH}$ & $9.06 \pm 0.83$ & $8.94 \pm 0.50$ & $10.22 \pm 1.20$ & $10.02 \pm 1.13$ & $9.74 \pm 1.35$ & $9.56 \pm 1.39$ & $9.20 \pm 1.14$ & $8.83 \pm 1.03$ & $5.5-9.0$ \\
\hline Temp. & $26.0 \pm 4.03$ & $25.9 \pm 4.22$ & $25.8 \pm 4.16$ & $25.7 \pm 4.17$ & $25.9 \pm 4.21$ & $26.2 \pm 4.15$ & $26.1 \pm 3.99$ & $26.1 \pm 3.92$ & - \\
\hline $\mathrm{EC}$ & $3.64 \pm 1.03$ & $3.85 \pm 1.21$ & $4.04 \pm 1.22$ & $3.99 \pm 1.24$ & $3.65 \pm 1.55$ & $3.59 \pm 1.30$ & $3.76 \pm 1.26$ & $3.29 \pm 1.62$ & - \\
\hline TDS & $952 \pm 69.44$ & $1019.5 \pm 145.84$ & $1115 \pm 142.71$ & $1064.5 \pm 139.72$ & $1024.5 \pm 123.77$ & $981 \pm 97.00$ & $1044.75 \pm 132.76$ & $965.75 \pm 60.15$ & 2100 \\
\hline $\mathrm{TH}$ & $60.92 \pm 16.66$ & $63.22 \pm 16.31$ & $65.56 \pm 17.09$ & $64.62 \pm 16.82$ & $63.53 \pm 16.97$ & $60.38 \pm 14.82$ & $57.69 \pm 11.71$ & $56.29 \pm 11.04$ & 250 \\
\hline BOD & $26.41 \pm 5.85$ & $26.19 \pm 5.54$ & $27.36 \pm 5.40$ & $26.95 \pm 5.63$ & $26.76 \pm 5.70$ & $27.25 \pm 5.59$ & $27.73 \pm 5.62$ & $26.92 \pm 5.73$ & 30 \\
\hline COD & $423.59 \pm 53.05$ & $417.63 \pm 54.85$ & $466.8 \pm 97.80$ & $461.6 \pm 96.59$ & $431 \pm 59.47$ & $424.1 \pm 61.15$ & $430.94 \pm 59.29$ & $415.42 \pm 62.89$ & 250 \\
\hline $\mathrm{NO}_{3}^{-}$ & $4.121 \pm 0.87$ & $3.970 \pm 0.92$ & $4.231 \pm 0.70$ & $3.995 \pm 0.82$ & $3.681 \pm 1.06$ & $3.916 \pm 0.57$ & $4.268 \pm 0.84$ & $3.889 \pm 0.67$ & 18 \\
\hline $\mathrm{PO}_{4}^{3-}$ & $0.567 \pm 0.10$ & $0.551 \pm 0.10$ & $0.6 \pm 0.09$ & $0.575 \pm 0.09$ & $0.556 \pm 0.09$ & $0.832 \pm 0.56$ & $1.111 \pm 1.06$ & $1.079 \pm 1.03$ & 5 \\
\hline $\mathrm{SO}_{4}^{2-}$ & $64.24 \pm 14.18$ & $61.58 \pm 15.04$ & $64.173 \pm 15.84$ & $62.405 \pm 15.66$ & $58.807 \pm 14.98$ & $55.72 \pm 14.83$ & $53.385 \pm 14.27$ & $49.765 \pm 13.20$ & 1000 \\
\hline $\mathrm{Cl}^{-}$ & $821.3 \pm 52.62$ & $764.7 \pm 60.76$ & $1144.2 \pm 113.75$ & $1091.5 \pm 122.11$ & $1046.1 \pm 141.98$ & $1015.7 \pm 150.13$ & $1050 \pm 150.46$ & $1018.1 \pm 141.57$ & 1000 \\
\hline $\mathrm{CN}^{-}$ & $0.696 \pm 0.70$ & $1.478 \pm 0.73$ & $1.345 \pm 0.65$ & $1.263 \pm 0.68$ & $1.185 \pm 0.69$ & $0.968 \pm 0.75$ & $0.833 \pm 0.77$ & $0.41 \pm 0.04$ & 0.2 \\
\hline $\mathrm{Na}^{+}$ & $323.5 \pm 50.72$ & $348.7 \pm 44.63$ & $371.7 \pm 45.22$ & $360.9 \pm 51.65$ & $353 \pm 56.37$ & $334.8 \pm 50.85$ & $343.7 \pm 49.31$ & $310.2 \pm 52.92$ & - \\
\hline $\mathrm{K}^{+}$ & $72.18 \pm 7.36$ & $77.93 \pm 10.44$ & $83.99 \pm 17.92$ & $80.12 \pm 15.72$ & $74.75 \pm 14.56$ & $71.58 \pm 13.01$ & $76.39 \pm 15.91$ & $64.38 \pm 9.11$ & - \\
\hline $\mathrm{Pb}$ & $2.8 \pm 0.47$ & $2.53 \pm 0.41$ & $2.94 \pm 0.45$ & $2.79 \pm 0.48$ & $2.47 \pm 0.33$ & $2.28 \pm 0.33$ & $2.18 \pm 0.29$ & $2.02 \pm 0.29$ & 0.1 \\
\hline $\mathrm{Cd}$ & $0.33 \pm 0.08$ & $0.312 \pm 0.07$ & $0.346 \pm 0.05$ & $0.333 \pm 0.05$ & $0.320 \pm 0.04$ & $0.304 \pm 0.04$ & $0.295 \pm 0.04$ & $0.283 \pm 0.05$ & 2 \\
\hline $\mathrm{Cr}$ & $0.548 \pm 0.15$ & $0.519 \pm 0.14$ & $0.488 \pm 0.13$ & $0.457 \pm 0.13$ & $0.434 \pm 0.12$ & $0.421 \pm 0.13$ & $0.4 \pm 0.12$ & $0.384 \pm 0.12$ & 2 \\
\hline $\mathrm{Fe}$ & $23.28 \pm 4.64$ & $22.27 \pm 4.84$ & $21.84 \pm 4.75$ & $20.85 \pm 4.41$ & $20.32 \pm 4.36$ & $19.32 \pm 4.21$ & $20.84 \pm 4.67$ & $18.49 \pm 3.51$ & 3 \\
\hline $\mathrm{Cu}$ & $0.256 \pm 0.05$ & $0.242 \pm 0.05$ & $0.228 \pm 0.04$ & $0.284 \pm 0.04$ & $0.265 \pm 0.03$ & $0.243 \pm 0.03$ & $0.225 \pm 0.03$ & $0.199 \pm 0.03$ & 3 \\
\hline $\mathrm{Ni}$ & $0.186 \pm 0.01$ & $0.173 \pm 0.01$ & $0.164 \pm 0.01$ & $0.204 \pm 0.03$ & $0.190 \pm 0.02$ & $0.173 \pm 0.02$ & $0.159 \pm 0.01$ & $0.139 \pm 0.01$ & 3 \\
\hline $\mathrm{Hg}$ & $0.625 \pm 0.14$ & $0.603 \pm 0.14$ & $0.996 \pm 0.35$ & $0.861 \pm 0.26$ & $0.647 \pm 0.14$ & $0.574 \pm 0.11$ & $0.489 \pm 0.07$ & $0.451 \pm 0.06$ & 0.01 \\
\hline
\end{tabular}

Units: $\mathrm{EC}$ in $\mathrm{mS} / \mathrm{cm}$, Temperature in $\left({ }^{\circ} \mathrm{C}\right)$ and all other parameters are expressed in $\mathrm{mg} / \mathrm{l}$

IS standard (1981) for discharge into inland waterbodies

- standard not mentioned 
water are higher than the IS standards at all sites except Site 1 and 2. The value for chloride is maximum at Site 3 $(1144.2 \pm 113.75 \mathrm{mg} / \mathrm{l})$ which may be attributed to the discharge of chlor-alkali wastewater at this site. Nitrate $\left(\mathrm{NO}_{3}{ }^{-}\right)$ and phosphate $\left(\mathrm{PO}_{4}{ }^{3-}\right)$ concentrations are quite low for all sites and very much within the permissible limits. Values of these parameters are highest at Site 7 (4.268 $\pm 0.84 \mathrm{mg} / \mathrm{l}$ and $1.111 \pm 1.06 \mathrm{mg} / \mathrm{l}$, respectively), which can be explained due to the intermixing of sewage water and runoffs from the nearby agricultural fields. Cyanide is an extremely toxic parameter in aquatic systems and contributed from industrial sources (Gupta et al. 2008). The cyanide concentrations in stream waters are higher than IS standard for all the sampling sites. The highest values occur at Site $2(1.478 \pm 0.65 \mathrm{mg} / \mathrm{l})$ due to the intermixing of coke-oven wastewater at this site and then showing decreasing trend with the lowest value at Site $8(0.41 \pm 0.04 \mathrm{mg} / \mathrm{l})$.

The presence of heavy metals in the aquatic environment is of major concern because of their persistence, toxicity and bio-accumulating tendency (Igwe and Abia 2003). Seven heavy metals like $\mathrm{Pb}, \mathrm{Cd}, \mathrm{Cr}, \mathrm{Fe}, \mathrm{Cu}, \mathrm{Ni}$ and $\mathrm{Hg}$ are analyzed (Table 2) and compared with the recommended standards for industrial effluents discharged into the surface waters (IS 1981). Total metal concentrations in channel waters are in the order of $\mathrm{Fe}>\mathrm{Pb}>\mathrm{Hg}>\mathrm{Cr}>\mathrm{Cd}>\mathrm{Cu}>\mathrm{Ni}$ (Table 2), of which mean concentration of Fe $(20.9 \pm 4.18 \mathrm{mg} / \mathrm{l}), \mathrm{Pb}$ $(2.5 \pm 0.46 \mathrm{mg} / \mathrm{l})$ and $\mathrm{Hg}(0.655 \pm 0.24 \mathrm{mg} / \mathrm{l})$ exceeds the IS discharge standards. Rest of the metal concentrations are well under the permissible limit. The result shows decreasing trend in metal concentrations from Site 1 to Site 8, with few exceptions for $\mathrm{Pb}, \mathrm{Cd}$ and $\mathrm{Hg}$ (at Site 3) and $\mathrm{Cu}$ and $\mathrm{Ni}$ at (Site 4). The high values of $\mathrm{Pb}, \mathrm{Cd}$ and $\mathrm{Hg}$ at Site 3 can be attributed to the discharge from chlor-alkali and ferro-alloy industries near to those stations, and the possible sources of $\mathrm{Cu}$ and $\mathrm{Ni}$ at Site 4 are from pharmaceutical effluents (Rai 2010; Gupta et al. 2013, James et al. 2013). The decrease metal concentrations in downstream may be due to the alkaline nature of the water that favors and accelerates metal deposition in bottom sediment (Salati and Moore 2010). Moreover, an increase in the volume of channel water in the downstream stretch may bring a dilution effect and reduce the metal concentrations at these sampling sites (Site 7 and Site 8).

\section{Seasonal variation of water parameters and heavy metals in stream water}

The seasonal variation of different physicochemical parameters and heavy metals is represented in (Table 3). Three distinct seasons, viz. pre-monsoon, monsoon and
Table 3 Seasonal variations of physicochemical parameters and heavy metal concentrations in stream water samples

\begin{tabular}{lccc}
\hline Parameters & Pre-monsoon (Summer) & Monsoon & Post-monsoon (Winter) \\
\hline $\mathrm{pH}$ & $10.50 \pm 0.88$ & $8.10 \pm 0.41$ & $9.94 \pm 0.62$ \\
$\mathrm{Temp}$. & $29.43 \pm 0.18$ & $26.95 \pm 0.20$ & $20.01 \pm 0.27$ \\
$\mathrm{EC}$ & $3.38 \pm 0.38$ & $5.58 \pm 0.27$ & $3.27 \pm 0.17$ \\
$\mathrm{TDS}$ & $1046.25 \pm 100.75$ & $1152 \pm 100.62$ & $970.25 \pm 56.53$ \\
$\mathrm{TH}$ & $75.23 \pm 6.46$ & $40.08 \pm 0.89$ & $67.49 \pm 3.56$ \\
$\mathrm{BOD}_{\mathrm{COD}}$ & $22.41 \pm 0.69$ & $35.17 \pm 0.47$ & $25.16 \pm 0.45$ \\
$\mathrm{NO}_{3}{ }^{-}$ & $509.65 \pm 52.93$ & $371.49 \pm 8.73$ & $470.24 \pm 9.06$ \\
$\mathrm{PO}_{4}{ }^{3-}$ & $3.66 \pm 0.36$ & $4.77 \pm 0.36$ & $3.12 \pm 0.40$ \\
$\mathrm{SO}_{4}{ }^{2-}$ & $0.45 \pm 0.03$ & $1.28 \pm 0.92$ & $0.64 \pm 0.04$ \\
$\mathrm{Cl}^{-}$ & $79.25 \pm 6.30$ & $49.00 \pm 5.30$ & $59.64 \pm 5.29$ \\
$\mathrm{CN}^{-}$ & $1096.15 \pm 160.58$ & $893.14 \pm 106.98$ & $1093.39 \pm 159.71$ \\
$\mathrm{Na}$ & $1.57 \pm 0.52$ & $0.48 \pm 0.28$ & $1.56 \pm 0.51$ \\
$\mathrm{~K}^{+}$ & $395.67 \pm 19.76$ & $276.39 \pm 21.34$ & $342.00 \pm 26.57$ \\
$\mathrm{~Pb}^{+}$ & $89.54 \pm 14.39$ & $65.49 \pm 4.88$ & $81.08 \pm 2.58$ \\
$\mathrm{Cd}$ & $2.86 \pm 0.40$ & $2.03 \pm 0.26$ & $2.65 \pm 0.46$ \\
$\mathrm{Cr}$ & $0.354 \pm 0.03$ & $0.240 \pm 0.03$ & $0.354 \pm 0.03$ \\
$\mathrm{Fe}$ & $0.554 \pm 0.07$ & $0.272 \pm 0.04$ & $0.546 \pm 0.06$ \\
$\mathrm{Cu}^{\mathrm{Ni}}$ & $23.39 \pm 1.89$ & $14.28 \pm 1.09$ & $23.10 \pm 1.84$ \\
$\mathrm{Hg}$ & $0.281 \pm 0.03$ & $0.191 \pm 0.03$ & $0.243 \pm 0.03$ \\
\hline & $0.189 \pm 0.03$ & $0.155 \pm 0.02$ & $0.177 \pm 0.02$ \\
$\mathrm{Na}^{-}$ & $0.762 \pm 0.25$ & $0.421 \pm 0.04$ & $0.734 \pm 0.24$ \\
\hline
\end{tabular}

Units: $\mathrm{EC}$ in $\mathrm{mS} / \mathrm{cm}$, temperature in $\left({ }^{\circ} \mathrm{C}\right)$ and all other parameters are expressed in $\mathrm{mg} / \mathrm{l}$ IS standard (1981) for discharge into inland waterbodies - standard not mentioned 
post-monsoon, are evident by the variation of temperature in the study area. The mean value of $\mathrm{pH}(10.50 \pm 0.88), \mathrm{TH}$ $(75.23 \pm 6.46 \mathrm{mg} / \mathrm{l}), \mathrm{COD}(509.65 \pm 52.93 \mathrm{mg} / \mathrm{l})$ and cations like $\mathrm{Na}^{+}(395.67 \pm 19.76 \mathrm{mg} / \mathrm{l})$ and $\mathrm{K}^{+}(89.54 \pm 14.39 \mathrm{mg} / \mathrm{l})$ and some anions such as $\mathrm{SO}_{4}{ }^{2-}(79.25 \pm 6.30 \mathrm{mg} / \mathrm{l})$, $\mathrm{Cl}^{-}(1096.15 \pm 160.58 \mathrm{mg} / \mathrm{l})$ and $\mathrm{CN}^{-}(1.57 \pm 0.52 \mathrm{mg} / \mathrm{l})$ are high in summer which can be corresponded to the lesser volume of water in the channel, and also due to the high rate of evaporation during this dry season. The higher mean value of TDS $(1152 \pm 100.62 \mathrm{mg} / \mathrm{l})$, BOD $(35.17 \pm 0.47 \mathrm{mg} / \mathrm{l})$ and anions like $\mathrm{NO}_{3}{ }^{-}(4.77 \pm 0.36 \mathrm{mg} / \mathrm{l})$ and $\mathrm{PO}_{4}{ }^{3-}(1.28 \pm 0.92 \mathrm{mg} / \mathrm{l})$ in monsoon can be linked to additional influx of surface runoff from surrounding areas. The decreasing trend of $\mathrm{pH}, \mathrm{TH}, \mathrm{COD}, \mathrm{SO}_{4}{ }^{2-}, \mathrm{Cl}^{-}, \mathrm{Na}^{+}$and $\mathrm{K}^{+}$during the monsoon is because of higher precipitation in this season. The lowest mean value of TDS and $\mathrm{NO}_{3}{ }^{-}$is seen in winter, while $\mathrm{BOD}$ and $\mathrm{PO}_{4}{ }^{3-}$ show the lowest value during the summer. Unlike other cations, metal ion concentrations in channel water also show higher value in summer and lower value during the monsoon. This situation can be explained due to the reduction and dilution of channel water in the respective season, consistent with earlier findings (Gupta et al. 2010a).

\section{Heavy metal concentration and its distribution in stream sediments}

The accumulation and distribution of heavy metal in bed sediments are affected by mineralogical composition, the presence of organic matter, anthropogenic influences and in situ process such as precipitation and adsorption (Jain et al. 2005). Physicochemical analysis of sediment samples (Table 4) shows that $\mathrm{pH}$ of channel sediments is highly alkaline (7.98-9.8) with EC value of 12.6-22.1 Ms/cm. Organic carbon content (\%) in channel sediments is in low range (1.02-1.36). Abundance of average metal contents in the sediments samples (Table 4) is in the order of Fe $>$ $\mathrm{Cu}>\mathrm{Cr}>\mathrm{Pb}>\mathrm{Cd}>\mathrm{Ni}>\mathrm{Hg}$. Unlike channel water, $\mathrm{Fe}$ is the most abundant metal in bed sediments, which can be attributed to its high concentration in ferro-alloy industrial wastewater and some extent due to lateritic soil type of the area. Lateritic soil, known for their high concentrations of iron oxides, releases iron in ionic form $\left(\mathrm{Fe}^{2+}\right.$ and $\left.\mathrm{Fe}^{3+}\right)$ in soil-water leading to higher iron content in soil (Schellmann 1986). However, rest of the metals in channel sediment do not strictly follow their abundance sequence as in the water samples. This may be due to the preferential chelation and deposition of some of the metals over the others (Salati and Moore 2010). The measured concentrations of heavy metals in all the sampling stations are notably higher than the baseline/background value (Table 4). Comparison of average metal contents with respect to sediment quality guidelines (SQGs) reveals that $\mathrm{Pb}, \mathrm{Cd}, \mathrm{Cr}$ and $\mathrm{Hg}$ is higher in concentrations than PEL and ERM standards (Table 4). Elevated metal concentration in channel sediments can be corresponded to the discharge of industrial and urban wastes into the channel and also alkaline nature of water which favors precipitation of metals and subsequent accumulation in channel sediments.
Table 4 Physicochemical characteristics and heavy metal concentrations in stream sediment samples

\begin{tabular}{lclllll}
\hline $\begin{array}{l}\text { Physicochemi- } \\
\text { cal parameters }\end{array}$ & $\begin{array}{l}\text { Analyzed value } \\
\text { (Mean } \pm \text { SD) }\end{array}$ & $\begin{array}{l}\text { Background } \\
\text { sediments } \\
\text { value }\end{array}$ & $\begin{array}{l}\text { Reference } \\
\text { value TEC }^{\mathrm{a}}\end{array}$ & $\begin{array}{l}\text { Reference } \\
\text { value PEC }^{\mathrm{b}}\end{array}$ & $\begin{array}{l}\text { Reference } \\
\text { value PEL }^{\mathrm{c}}\end{array}$ & $\begin{array}{l}\text { Refer- } \\
\text { ence value }^{\text {ERM }^{\mathrm{d}}}\end{array}$ \\
\hline $\mathrm{pH}$ & $8.94 \pm 0.64$ & 7.54 & - & - & - & - \\
$\mathrm{EC}$ & $17.46 \pm 3.22$ & 18.6 & - & - & - & - \\
$\mathrm{OC}$ & $1.19 \pm 0.11$ & 2.86 & - & - & - & - \\
$\mathrm{OM}$ & $2.04 \pm 0.19$ & 4.92 & - & - & - & - \\
$\mathrm{Pb}$ & $138.18 \pm 16.04$ & 11.4 & 35.80 & 128.00 & 91.3 & 110 \\
$\mathrm{Cd}$ & $57.29 \pm 14.42$ & 4.8 & 0.99 & 4.98 & 3.53 & 9 \\
$\mathrm{Cr}$ & $204.86 \pm 33.45$ & 14.2 & 43.40 & 111.00 & 90 & 145 \\
$\mathrm{Fe}$ & $442.45 \pm 27.53$ & 148 & - & - & - & - \\
$\mathrm{Cu}$ & $55.83 \pm 9.68$ & 22.46 & 31.60 & 149.00 & 197 & 390 \\
$\mathrm{Ni}$ & $30.18 \pm 1.68$ & 2.28 & 22.70 & 48.60 & 36 & 50 \\
$\mathrm{Hg}$ & $3.44 \pm 0.77$ & 0.011 & 0.18 & 1.06 & 0.486 & 1.3 \\
\hline
\end{tabular}

Units: $\mathrm{EC}$ in $\mathrm{mS} / \mathrm{cm}$, organic $\mathrm{C}$ in \% and all other parameters in $\mathrm{mg} / \mathrm{kg}$

${ }^{a}$ TEC Threshold effect concentrations (MacDonald et al. 2000)

${ }^{\mathrm{b}}$ PEC Probable effect concentrations (MacDonald et al. 2000)

${ }^{\mathrm{c}}$ PEL Probable effect level (MacDonald et al. 2000)

${ }^{\mathrm{d}}$ ERM Effect range-median (MacDonald et al. 2000) 


\section{Evaluation of heavy metal contamination by using indices}

The concentration of metals in water and sediments can be a sensitive indicator of contaminants in the hydrological system (Jain et al. 2005). Elevated concentrations of metals in water and sediments are often related to toxic effects on the aquatic ecosystem. Contamination factor $\left(C_{\mathrm{f}}\right)$, contamination index $\left(C_{\mathrm{d}}\right)$ and modified contamination index $\left(\mathrm{mC}_{\mathrm{d}}\right)$ were successfully used by earlier workers (Edet and Offiong 2002; Jain et al. 2005; Abrahim and Parker 2008; Gupta et al. 2010a; Nayek et al. 2013) singly or in combination with assessment of heavy metal enrichment and contamination in water and sediments.

The picture of heavy metal contamination in channel water with respect to $C_{\mathrm{f}}, C_{\mathrm{d}}$ and $\mathrm{mC}_{\mathrm{d}}$ values is presented in Table 5. Mean $C_{\mathrm{f}}$ value of heavy metals in channel water follows the order of $\mathrm{Hg}>\mathrm{Pb}>\mathrm{Fe}>\mathrm{Cr}>\mathrm{Cd}>\mathrm{Cu}>\mathrm{Ni}$. The $C_{\mathrm{f}}$ values of $\mathrm{Hg}, \mathrm{Pb}$ and $\mathrm{Fe}$ at all sampling sites reveal very high contamination. The contamination index $\left(C_{\mathrm{d}}\right)$ values for heavy metals at all sampling stations indicate the very high degree of contamination (Table 5). Similarly, the measured $\mathrm{mC}_{\mathrm{d}}$ values of channel water samples at most of the sampling stations are also high, whereas at Site 3 and Site 4 (>16) they show extremely high contamination (Table 5). The high contamination of channel water can be attributed to the direct discharge of industrial effluents and urban wastewater and disposal of waste materials over time.

Enrichment factor (EF), geo-accumulation index $\left(I_{\text {geo }}\right)$ and pollution load index (PLI) are often used for quantitative measurement of metal pollution in sediments. The average EF values of heavy metals in channel sediments (Table 6) follow the sequence of $\mathrm{Hg}>\mathrm{Cr}>\mathrm{Ni}>\mathrm{Pb}>\mathrm{Cd}>\mathrm{Fe}>\mathrm{Cu}$. Among the studied metals, $\mathrm{Hg}$ shows extremely high enrichment at all sampling sites, while the enrichments of $\mathrm{Cr}, \mathrm{Ni}$, $\mathrm{Pb}$ and $\mathrm{Cd}$ are categories as significant enrichment in surface sediments. $\mathrm{Cu}$ shows moderate enrichment at all sites except Site 7 and 8, where it shows minimal enrichment. This can pose a long-term environmental hazard as there may be the possibility of heavy metals leaching into soil layers (Lu et al. $2015)$. The mean $I_{\text {geo }}$ value of heavy metals in channel sediments (Fig. 2) is in the order of $\mathrm{Hg}(7.67)>\mathrm{Cr}(3.25)>\mathrm{Ni}$
Table 5 Contamination factors $\left(C_{\mathrm{f}}\right)$, degree of contamination $\left(C_{\mathrm{d}}\right)$ and modified degree of contamination $\left(\mathrm{mC}_{\mathrm{d}}\right)$ of heavy metals in stream water samples

Table 6 Enrichment factors (EF) and pollution load index (PLI) of heavy metals for sediment samples

\begin{tabular}{|c|c|c|c|c|c|c|c|c|c|}
\hline \multirow[t]{2}{*}{ Sites } & \multicolumn{7}{|l|}{$C_{\mathrm{f}}$} & \multirow[t]{2}{*}{$C_{\mathrm{d}}$} & \multirow[t]{2}{*}{$\mathrm{mC}_{\mathrm{d}}$} \\
\hline & $\mathrm{Pb}$ & $\mathrm{Cd}$ & $\mathrm{Cr}$ & $\mathrm{Fe}$ & $\mathrm{Cu}$ & $\mathrm{Ni}$ & $\mathrm{Hg}$ & & \\
\hline Site 1 & 27.96 & 0.17 & 0.27 & 7.76 & 0.09 & 0.06 & 62.48 & 98.78 & 14.11 \\
\hline Site 2 & 25.26 & 0.16 & 0.26 & 7.42 & 0.08 & 0.06 & 60.25 & 93.48 & 13.35 \\
\hline Site 3 & 29.40 & 0.17 & 0.24 & 7.28 & 0.08 & 0.05 & 99.60 & 136.83 & 19.55 \\
\hline Site 4 & 27.89 & 0.17 & 0.23 & 6.95 & 0.09 & 0.07 & 86.10 & 121.50 & 17.36 \\
\hline Site 5 & 24.70 & 0.16 & 0.22 & 6.77 & 0.09 & 0.06 & 64.65 & 96.65 & 13.81 \\
\hline Site 6 & 22.84 & 0.15 & 0.21 & 6.44 & 0.08 & 0.06 & 57.35 & 87.13 & 12.45 \\
\hline Site 7 & 21.75 & 0.15 & 0.20 & 6.95 & 0.07 & 0.05 & 48.85 & 78.02 & 11.15 \\
\hline Site 8 & 20.20 & 0.14 & 0.19 & 6.16 & 0.07 & 0.05 & 45.10 & 71.91 & 10.27 \\
\hline Min & 20.20 & 0.14 & 0.19 & 6.16 & 0.07 & 0.05 & 45.10 & 71.91 & 10.27 \\
\hline Max & 29.40 & 0.17 & 0.27 & 7.76 & 0.09 & 0.07 & 99.60 & 136.83 & 19.55 \\
\hline Mean & 25.00 & 0.16 & 0.23 & 6.97 & 0.08 & 0.06 & 65.55 & 98.04 & 14.01 \\
\hline
\end{tabular}

\begin{tabular}{|c|c|c|c|c|c|c|c|c|}
\hline \multirow[t]{2}{*}{ Sites } & \multicolumn{7}{|l|}{$\mathrm{EF}$} & \multirow[t]{2}{*}{ PLI } \\
\hline & $\mathrm{Pb}$ & $\mathrm{Cd}$ & $\mathrm{Cr}$ & $\mathrm{Fe}$ & $\mathrm{Cu}$ & $\mathrm{Ni}$ & $\mathrm{Hg}$ & \\
\hline Site1 & 12.62 & 15.13 & 17.33 & 3.31 & 2.84 & 13.80 & 313.64 & 14.49 \\
\hline Site2 & 10.78 & 14.03 & 16.72 & 3.19 & 2.77 & 13.36 & 294.55 & 13.64 \\
\hline Site3 & 14.72 & 15.73 & 16.17 & 3.06 & 2.62 & 12.82 & 420.00 & 14.88 \\
\hline Site4 & 13.03 & 13.00 & 15.41 & 2.94 & 2.95 & 14.29 & 374.55 & 14.28 \\
\hline Site 5 & 12.42 & 11.71 & 13.96 & 2.87 & 2.68 & 13.80 & 349.09 & 13.34 \\
\hline Site6 & 11.91 & 9.03 & 13.21 & 2.75 & 2.33 & 13.28 & 301.82 & 12.03 \\
\hline Site7 & 11.12 & 8.58 & 11.44 & 2.95 & 1.89 & 12.34 & 256.36 & 10.98 \\
\hline Site8 & 10.36 & 8.28 & 11.18 & 2.86 & 1.82 & 12.19 & 192.73 & 10.23 \\
\hline Min & 10.36 & 8.28 & 11.18 & 2.75 & 1.82 & 12.19 & 192.73 & 10.23 \\
\hline Max & 14.72 & 15.73 & 17.33 & 3.31 & 2.95 & 14.29 & 420.00 & 14.88 \\
\hline Mean & 12.12 & 11.93 & 14.43 & 2.99 & 2.49 & 13.24 & 312.84 & 12.98 \\
\hline
\end{tabular}




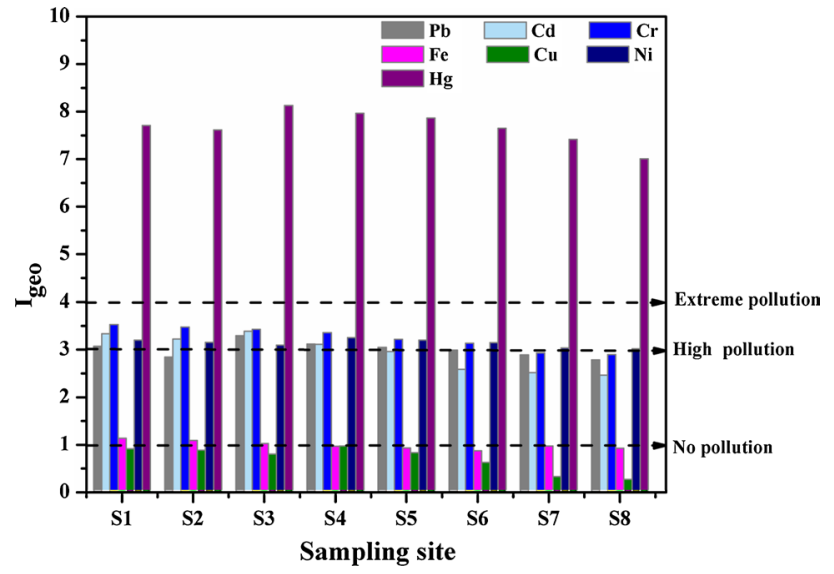

Fig. 2 Geo-accumulation index $\left(I_{\text {geo }}\right)$ of heavy metals for sediment samples in various sampling sites

(3.14) $>\mathrm{Pb}(3.01)>\mathrm{Cd}(2.95)>\mathrm{Fe}(0.99)>\mathrm{Cu}(0.71)$, consistent with the enrichment factors (EF) in channel sediments. The $I_{\text {geo }}$ values for $\mathrm{Cu}$ at all sites are $<1$ indicating no pollution in channel sediments (Fig. 2). Similarly, the $I_{\text {geo }}$ values of $\mathrm{Fe}$ at Site 4 to Site 8 are $<1$, indicating no pollution at these sampling stations. The $I_{\text {geo }}$ values for $\mathrm{Cr}$ at Site 7, 8, $\mathrm{Pb}$ at Site 2, 6, 7, 8 and $\mathrm{Cd}$ at Site 5, 6, 7, 8 show moderate pollution. $I_{\text {geo }}$ values of $\mathrm{Ni}$ at all sites, $\mathrm{Cr}$ at Site 1 to Site 6 and $\mathrm{Pb}$ at Site 1, 3, 4, 5 and $\mathrm{Cd}$ at Site 1 to Site 4 indicate high pollution (Fig. 2). The highest $I_{\text {geo }}$ value is observed for $\mathrm{Hg}$ at all the sampling sites, exhibiting "extremely polluted" condition of channel sediments. Strong positive correlations $(p<0.05)$ between EF with $I_{\text {geo }}$ values for heavy metals may be due to similar levels of metal enrichment and accumulation rate/pattern in channel sediments. Pollution load index (PLI) for heavy metals, viz. in channel sediments, was computed for each sampling station. The integrated PLI of heavy metals in sediment samples ranged from 10.23 to 14.98 (Table 6), indicating the very high degree of metal pollution (PLI $>1)$ in channel sediments.

\section{Ecological risk assessment}

The potential environmental risk of heavy metals in water sediments is associated with both their total content and their speciation (Jain et al. 2005; Nayek et al. 2013). Two sets of guidelines are commonly used to evaluate ecotoxicity of heavy metals in sediments; the effects range low/ median (ERL/ERM) and threshold/probable effect level (TEL/PEL). Probable effect level (PEL) and effective range medium (ERM) represent chemical concentrations above which adverse effects are likely to occur (MacDonald et al. 2000). Among the studied metals, only $\mathrm{Cu}$ and $\mathrm{Ni}$ are lower in concentration than the recommended sediment quality guidelines (SQGs) for probable effect level (PEC). For a more realistic measure of the sediment toxicity, mean quotients were introduced (Shakeri et al. 2016).

PELQ $=\frac{\sum_{i=1}^{n} M_{i} / \mathrm{PEL}_{i}}{n}$,

$\mathrm{ERMQ}=\frac{\sum_{i=1}^{n} \mathrm{M}_{i} / \mathrm{ERM}_{i}}{n}$,

where the PELQ and ERMQ factors are the average ratios between the metal concentration in the channel sediment samples $\left(M_{i}\right)$ and the related PEL and ERM values for the element $i\left(\mathrm{PEL}_{i}, \mathrm{ERM}_{i}\right)$ and $\mathrm{n}$ is the number of metals. The gradation of sediment quality based on PELQ and ERMQ value is shown in Table 7. The calculated PELQ and ERMQ for the heavy metals in channel sediments at various sampling sites are represented in Fig. 3. Sediment samples based on these factors are highly toxic in heavy metal content for all the sampling stations except Site $8(E R M Q=$ moderate toxic).

The potential ecological risk index (RI) is used to evaluate the toxicity of metals in the sediment (Hakanson 1980). According to this method, the potential ecological risk factor $\left(E_{r}^{i}\right)$ for a single element and the potential ecological RI of multi-element can be computed by the following equation:

$\mathrm{RI}=\sum_{i=1}^{n} E_{r}^{i}=\sum_{i=1}^{n} C_{\mathrm{f}}^{i} \times T_{r}^{i}$

where $\mathrm{C}_{\mathrm{f}}^{i}$ is the contamination factor for the element " $i$ " and $T_{\mathrm{r}}$ is the toxic response factor for the given element of " $\mathrm{i}$,", which accounts for the toxic and the sensitivity requirements. The toxic response factors for $\mathrm{Pb}, \mathrm{Cd}, \mathrm{Cr}, \mathrm{Cu}, \mathrm{Hg}$

Table 7 Classification of $\mathrm{E}_{\mathrm{r}}$, RI (Hakanson 1980), PELQ and ERMQ (MacDonald et al. 2000)

\begin{tabular}{llllllll}
\hline Value & Potential risk & Value & Ecological risk & Value & Degree of toxicity & Value & Degree of toxicity \\
\hline$E_{r}<40$ & Low & $\mathrm{RI}<150$ & Low & PELQ $<0.1$ & Non toxic & ERMQ $<0.1$ & Non toxic \\
$40<E_{r}<80$ & Moderate & $150<\mathrm{RI}<300$ & Moderate & $0.1<$ PELQ $<1.5$ & Slightly toxic & $0.1<$ ERMQ $<0.5$ & Slightly toxic \\
$80<E_{r}<160$ & High & $300<\mathrm{RI}<600$ & High & $1.5<$ PELQ $<2.3$ & Moderately toxic & $0.5<$ ERMQ $<1.5$ & Moderately toxic \\
$160<E_{\mathrm{f}}<320$ & Very High & $\mathrm{RI}>600$ & Very High & PELQ $>2.3$ & Highly toxic & ERMQ $>1.5$ & Highly toxic \\
$E_{\mathrm{f}}>320$ & Dangerous & & & & & & \\
\hline
\end{tabular}




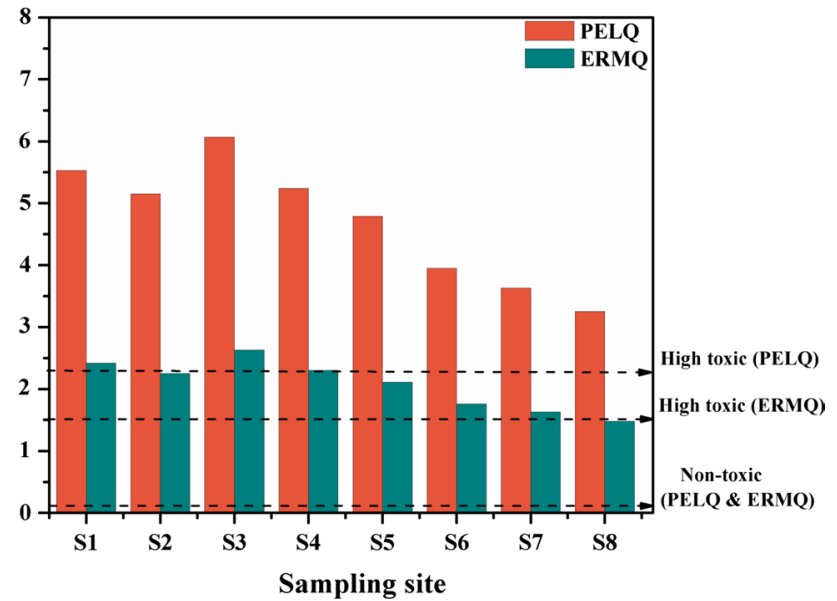

Fig. 3 PELQ and ERMQ of heavy metals for sediment samples in various sampling sites

and $\mathrm{Ni}$ were 5, 30, 2, 5, 40 and 5, respectively. Metal (viz. $\mathrm{Fe})$ with $\mathrm{E}_{\mathrm{r}}$ value $<1$ is not considered for the calculations of RI. The gradation of $E_{r}$, RI, and degree of toxicity levels are shown in Table 7. The potential risk factor for individual metal in channel sediments is in the sequence of $\mathrm{Cd}>\mathrm{Hg}>\mathrm{Pb}>\mathrm{Ni}>\mathrm{Cr}>\mathrm{Cu}$. The $\mathrm{E}_{\mathrm{r}}$ values for $\mathrm{Cd}$ at different sampling stations exhibit high (Site 6,7 and 8) to very high (Site 1 to 5) risk level, while $\mathrm{Hg}$ falls under the category of high risk except Site 8 (medium risk). The rest of the metals are very much under the low-risk category at all sampling stations (Table 8). The calculated ecological risk index (RI) values (Table 8) with respect to SQGs (PEL \& ERM) for all monitored stations are classified under the category of moderate-high risk level.

\section{Multivariate statistical approach}

Multivariate statistical analyses are carried out to assess the dynamics of metal distribution and identify the potential sources in water and sediments. The correlation between two variables reflects the degree to which the variables are related.

The Pearson's correlation matrix of the various water parameters is presented in Table 9. Strong positive correlation occurs between $\mathrm{pH}$ and $\mathrm{Na}^{+}$and $\mathrm{pH}-\mathrm{K}^{+}$revealing that alkaline nature of channel water is contributed by highly alkaline sodium and potassium hydroxides coming from the industrial source. High concentration of strong hydroxides especially sodium hydroxide $(\mathrm{NaOH})$ and potassium hydroxide $(\mathrm{KOH})$ is common in industrial effluents as they are used for industrial processing (such as process catalyst and caustic agent) and cleaning purposes (Nyamangara et al. 2007). Water pH shows significant positive correlation with $\mathrm{TH}, \mathrm{COD}$, and anions, viz. $\mathrm{SO}_{4}{ }^{2-}, \mathrm{Cl}^{-}$and $\mathrm{CN}^{-}$. Biogenic nutrients, viz. $\mathrm{NO}_{3}{ }^{-}$and $\mathrm{PO}_{4}{ }^{3-}$, show significant positive correlations with $\mathrm{BOD}$ and negatively correlation with $\mathrm{COD}$, whereas $\mathrm{SO}_{4}{ }^{2-}$ and $\mathrm{Cl}^{-}$execute strong positive correlations with COD indicating their industrial source. Besides, the strong correlation also exists between TDS and $\mathrm{EC}, \mathrm{Na}^{+}-\mathrm{TH}, \mathrm{COD}-\mathrm{K}^{+}, \mathrm{COD}-\mathrm{CN}^{-}$. The significant positive correlation was noted between $\mathrm{pH}$ with all the heavy metals. TH shows strong positive correlation with $\mathrm{Cd}, \mathrm{Cr}$ and $\mathrm{Fe}$. COD shows significant positive correlation with $\mathrm{Pb}, \mathrm{Cd}$ and $\mathrm{Cr}$, whereas $\mathrm{BOD}$ is negatively correlated with $\mathrm{Pb}, \mathrm{Cd}, \mathrm{Cr}$, $\mathrm{Fe}$ and $\mathrm{Cu}$. Heavy metal loading and high $\mathrm{pH}$ of the channel water reduce the biodegradability of the wastewater, thereby reducing BOD (Wang et al. 2002). Among heavy metals, $\mathrm{Pb}-\mathrm{Cd}, \mathrm{Pb}-\mathrm{Cr}, \mathrm{Pb}-\mathrm{Fe}, \mathrm{Pb}-\mathrm{Hg}, \mathrm{Cd}-\mathrm{Cr}, \mathrm{Cd}-\mathrm{Fe}, \mathrm{Cd}-\mathrm{Cu}$, $\mathrm{Cd}-\mathrm{Hg}, \mathrm{Cr}-\mathrm{Fe}, \mathrm{Cr}-\mathrm{Cu}$ and $\mathrm{Cu}-\mathrm{Ni}$ have strong positive correlations (Table 9), indicating that their primary sources are the same, i.e., industrial discharge. These heavy metals are widely used as raw materials or process catalysts to produce alloys and steels and various other industrial purposes. As a result, they are found in significant quantities in industrial wastes/wastewater which are discharged into the Tamla channel (Gupta et al. 2013). In addition, deposition of heavy metals through industrial emissions can also be recognized as a source of metal contamination in the study area. The high correlation between heavy metals may be due to their
Table 8 Potential ecological risk factors $\left(E_{r}^{i}\right)$ and potential ecological risk indexes (RI) of heavy metals in sediment samples

\begin{tabular}{|c|c|c|c|c|c|c|c|}
\hline \multirow[t]{2}{*}{ Sample Site } & \multicolumn{6}{|l|}{$\mathrm{Er}$} & \multirow[t]{2}{*}{ RI } \\
\hline & $\mathrm{Pb}$ & $\mathrm{Cd}$ & $\mathrm{Cr}$ & $\mathrm{Cu}$ & $\mathrm{Ni}$ & $\mathrm{Hg}$ & \\
\hline Site1 & 6.54 & 242.00 & 3.39 & 0.82 & 3.15 & 106.15 & 362.05 \\
\hline Site2 & 5.59 & 224.40 & 3.27 & 0.80 & 3.05 & 99.69 & 336.80 \\
\hline Site3 & 7.63 & 251.67 & 3.17 & 0.75 & 2.92 & 142.15 & 408.29 \\
\hline Site4 & 6.75 & 208.00 & 3.02 & 0.85 & 3.26 & 126.77 & 348.65 \\
\hline Site 5 & 6.44 & 187.33 & 2.73 & 0.77 & 3.15 & 118.15 & 318.58 \\
\hline Site6 & 5.81 & 144.43 & 2.59 & 0.67 & 3.03 & 102.15 & 258.68 \\
\hline Site7 & 5.76 & 137.33 & 2.38 & 0.54 & 2.81 & 86.77 & 235.60 \\
\hline Site8 & 5.55 & 129.13 & 2.33 & 0.52 & 2.78 & 65.23 & 205.55 \\
\hline Mean & 6.26 & 190.54 & 2.86 & 0.72 & 3.02 & 105.88 & 309.27 \\
\hline
\end{tabular}


Table 9 Pearson's correlation matrix of analyzed variables for water samples

\begin{tabular}{|c|c|c|c|c|c|c|c|c|c|c|c|}
\hline Variables & PH & Temp. & EC & TDS & $\mathrm{TH}$ & BOD & COD & $\mathrm{NO}_{3}^{-}$ & $\mathrm{PO}_{4}^{3-}$ & $\mathrm{SO}_{4}^{2-}$ & $\mathrm{Cl}^{-}$ \\
\hline $\mathrm{pH}$ & 1 & & & & & & & & & & \\
\hline Temp. & -0.069 & 1 & & & & & & & & & \\
\hline $\mathrm{EC}$ & -0.489 & 0.101 & 1 & & & & & & & & \\
\hline TDS & -0.216 & 0.214 & 0.756 & 1 & & & & & & & \\
\hline TH & 0.856 & -0.040 & -0.738 & -0.413 & 1 & & & & & & \\
\hline BOD & -0.760 & 0.005 & 0.865 & 0.584 & -0.949 & 1 & & & & & \\
\hline COD & 0.848 & -0.103 & -0.325 & -0.013 & 0.776 & -0.653 & 1 & & & & \\
\hline $\mathrm{NO}_{3}^{-}$ & -0.546 & 0.537 & 0.408 & 0.274 & -0.645 & 0.580 & -0.669 & 1 & & & \\
\hline $\mathrm{PO}_{4}^{3-}$ & -0.545 & 0.004 & 0.508 & 0.309 & -0.566 & 0.623 & -0.399 & 0.238 & 1 & & \\
\hline $\mathrm{SO}_{4}^{2-}$ & 0.718 & 0.187 & -0.154 & 0.135 & 0.706 & -0.580 & 0.857 & -0.508 & -0.452 & 1 & \\
\hline $\mathrm{Cl}^{-}$ & 0.744 & -0.215 & -0.165 & 0.114 & 0.456 & -0.342 & 0.709 & -0.473 & -0.181 & 0.431 & 1 \\
\hline $\mathrm{CN}^{-}$ & 0.729 & -0.291 & -0.194 & 0.103 & 0.651 & -0.520 & 0.789 & -0.689 & -0.420 & 0.701 & 0.613 \\
\hline $\mathrm{Na}^{+}$ & 0.843 & 0.203 & -0.660 & -0.263 & 0.913 & -0.870 & 0.700 & -0.374 & -0.620 & 0.680 & 0.463 \\
\hline $\mathrm{K}^{+}$ & 0.784 & -0.064 & -0.127 & 0.160 & 0.687 & -0.517 & 0.901 & -0.538 & -0.381 & 0.855 & 0.591 \\
\hline $\mathrm{Pb}$ & 0.712 & -0.049 & -0.440 & -0.161 & 0.786 & -0.660 & 0.703 & -0.394 & -0.573 & 0.734 & 0.308 \\
\hline $\mathrm{Cd}$ & 0.807 & -0.244 & -0.649 & -0.326 & 0.923 & -0.852 & 0.766 & -0.667 & -0.561 & 0.681 & 0.464 \\
\hline $\mathrm{Cr}$ & 0.724 & -0.220 & -0.661 & -0.438 & 0.907 & -0.881 & 0.707 & -0.652 & -0.615 & 0.702 & 0.253 \\
\hline $\mathrm{Fe}$ & 0.690 & -0.145 & -0.802 & -0.572 & 0.906 & -0.923 & 0.582 & -0.513 & -0.615 & 0.528 & 0.209 \\
\hline $\mathrm{Cu}$ & 0.712 & 0.146 & -0.562 & -0.315 & 0.829 & -0.778 & 0.576 & -0.440 & -0.553 & 0.632 & 0.249 \\
\hline $\mathrm{Ni}$ & 0.648 & 0.012 & -0.292 & -0.181 & 0.623 & -0.521 & 0.530 & -0.381 & -0.569 & 0.608 & 0.243 \\
\hline $\mathrm{Hg}$ & 0.743 & -0.102 & -0.399 & -0.125 & 0.727 & -0.565 & 0.618 & -0.301 & -0.399 & 0.515 & 0.470 \\
\hline Variables & $\mathrm{CN}^{-}$ & $\mathrm{Na}^{+}$ & $\mathrm{K}^{+}$ & $\mathrm{Pb}$ & 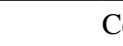 & & & & $\mathrm{Cu}$ & $\mathrm{Ni}$ & $\mathrm{Hg}$ \\
\hline
\end{tabular}

$\mathrm{pH}$

Temp.

EC

TDS

TH

BOD

COD

$\mathrm{NO}_{3}{ }^{-}$

$\mathrm{PO}_{4}^{3-}$

$\mathrm{SO}_{4}{ }^{2-}$

$\mathrm{Cl}^{-}$

$\mathrm{CN}^{-} \quad \mathbf{1}$

$\mathrm{Na}^{+} \quad 0.601 \quad 1$

$\begin{array}{llll}\mathrm{K}^{+} & 0.821 & 0.658 & \mathbf{1}\end{array}$

$\begin{array}{lllll}\mathrm{Pb} & 0.515 & \mathbf{0 . 7 5 3} & 0.673 & \mathbf{1}\end{array}$

$\begin{array}{llllll}\mathrm{Cd} & 0.626 & \mathbf{0 . 8 1 4} & 0.664 & \mathbf{0 . 8 5 5} & \mathbf{1}\end{array}$

$\begin{array}{lllllll}\mathrm{Cr} & 0.611 & 0.760 & 0.643 & \mathbf{0 . 8 2 0} & \mathbf{0 . 9 3 2} & \mathbf{1}\end{array}$

$\begin{array}{llllllll}\mathrm{Fe} & 0.459 & \mathbf{0 . 8 1 6} & 0.518 & \mathbf{0 . 7 6 5} & \mathbf{0 . 8 9 1} & \mathbf{0 . 9 3 9} & \mathbf{1}\end{array}$

$\begin{array}{lllllllll}\mathrm{Cu} & 0.439 & \mathbf{0 . 8 1 6} & 0.521 & \mathbf{0 . 7 2 8} & \mathbf{0 . 7 8 9} & \mathbf{0 . 7 4 7} & \mathbf{0 . 7 6 1} & \mathbf{1}\end{array}$

$\begin{array}{lllllllllll}\mathrm{Ni} & 0.470 & 0.618 & 0.558 & \mathbf{0 . 6 9 5} & 0.604 & 0.598 & 0.547 & \mathbf{0 . 8 3 8} & \mathbf{1} & \\ \mathrm{Hg} & 0.517 & 0.723 & 0.590 & \mathbf{0 . 8 4 7} & \mathbf{0 . 7 6 2} & 0.653 & 0.657 & 0.642 & 0.544 & \mathbf{1}\end{array}$

Values in bold are different from 0 with a significance level alpha $=0.05$

similar type of distribution pattern, or may be because of similar pollution level and similar pollution source, i.e., industrial discharge (Sun et al. 2010).
To gain further insight into the source and nature of the pollutants, factor analysis with varimax rotation is used to identify a small number of factors which explain most of the 
indices observed in water quality monitoring. Three factors account for cumulative variance of $77.84 \%$ (eigenvalue $>1$ ) for the channel water samples. The factor loading matrix, eigenvalues and variances are given in Table 10 . The overwhelming $59.342 \%$ of the total variance is contributed by $\mathrm{F} 1$, showing strong positive loading for $\mathrm{pH}, \mathrm{COD}, \mathrm{SO}_{4}{ }^{2-}$,

Table 10 Factor loading matrix (after varimax rotation), eigenvalues and variances for water samples

\begin{tabular}{|c|c|c|c|}
\hline Variables & F1 & $\mathrm{F} 2$ & F3 \\
\hline $\mathrm{pH}$ & 0.767 & 0.503 & -0.094 \\
\hline Temp. & -0.018 & -0.038 & 0.779 \\
\hline $\mathrm{EC}$ & 0.015 & -0.912 & 0.175 \\
\hline TDS & 0.322 & -0.752 & 0.238 \\
\hline $\mathrm{TH}$ & 0.601 & 0.775 & -0.078 \\
\hline BOD & -0.391 & -0.880 & 0.083 \\
\hline COD & 0.886 & 0.287 & -0.176 \\
\hline $\mathrm{NO}_{3}^{-}$ & -0.494 & -0.343 & 0.623 \\
\hline $\mathrm{PO}_{4}^{3-}$ & -0.327 & -0.574 & -0.084 \\
\hline $\mathrm{SO}_{4}^{2-}$ & 0.865 & 0.244 & 0.171 \\
\hline $\mathrm{Cl}^{-}$ & 0.639 & 0.045 & -0.296 \\
\hline $\mathrm{CN}^{-}$ & 0.813 & 0.170 & -0.328 \\
\hline $\mathrm{Na}^{+}$ & 0.609 & 0.700 & 0.198 \\
\hline $\mathrm{K}^{+}$ & 0.928 & 0.155 & -0.060 \\
\hline $\mathrm{Pb}$ & 0.643 & 0.565 & 0.126 \\
\hline $\mathrm{Cd}$ & 0.616 & 0.703 & -0.184 \\
\hline $\mathrm{Cr}$ & 0.524 & 0.757 & -0.157 \\
\hline $\mathrm{Fe}$ & 0.355 & 0.892 & -0.086 \\
\hline $\mathrm{Cu}$ & 0.502 & 0.702 & 0.225 \\
\hline $\mathrm{Ni}$ & 0.538 & 0.460 & 0.166 \\
\hline $\mathrm{Hg}$ & 0.589 & 0.480 & 0.027 \\
\hline Eigenvalue & 13.055 & 2.552 & 1.517 \\
\hline Variability (\%) & 59.342 & 11.599 & 6.897 \\
\hline Cumulative (\%) & 59.342 & 70.941 & 77.838 \\
\hline
\end{tabular}

Values in bold correspond to each variable to the factor for which the squared cosine is the largest
$\mathrm{Cl}^{-}, \mathrm{CN}^{-}, \mathrm{K}^{+}, \mathrm{Pb}, \mathrm{Ni}$ and $\mathrm{Hg}$, which seems to be related with the direct discharge of industrial effluents. Therefore, in F1, major contribution comes from industrial discharge, attributed to anthropogenic activities, and may be considered as "industrial factor." The second factor F2 explains $11.599 \%$ of the total variance and shows strong positive loading for $\mathrm{TH}, \mathrm{Na}^{+}, \mathrm{Fe}, \mathrm{Cd}, \mathrm{Cr}$ and $\mathrm{Cu}$ and strong negative loadings for TDS, BOD and $\mathrm{PO}_{4}{ }^{3-}$ which can be corresponded to runoff from surrounding agricultural fields and surface runoff influenced by both agricultural process and lithogenic factors. The third factor F3 covers $6.897 \%$ of the total variance and includes strong positive loading for temperature and $\mathrm{NO}_{3}{ }^{-}$which can be considered as "temporal factor" as $\mathrm{NO}_{3}{ }^{-}$is highly influenced by temporal variation (Wakawa et al. 2010). Some metals emerge at both F1 and F2, presumably due to the characteristics of heavy metals resulting from anthropogenic contamination.

Pearson's correlation (Table 11) for the surface sediment parameters shows negative correlation between $\mathrm{pH}-\mathrm{OC}$. Sediment $\mathrm{EC}$ is positively correlated with $\mathrm{Fe}, \mathrm{Cr}, \mathrm{Cu}, \mathrm{Cd}$ and $\mathrm{Hg}$, whereas OC shows negative correlation with most of the metals. Sediment $\mathrm{pH}$ is positively correlated with $\mathrm{Pb}, \mathrm{Cd}, \mathrm{Cr}$, $\mathrm{Cu}, \mathrm{Ni}$ and $\mathrm{Hg}$, which is associated with the low mobility of these elements in the alkaline environment, and favors their adsorption and precipitation in channel sediment (Gao et al. 2013). High degree of positive correlation between specific metals (viz. $\mathrm{Cu}-\mathrm{Ni}, \mathrm{Cu}-\mathrm{Cd}, \mathrm{Cu}-\mathrm{Cr}, \mathrm{Pb}-\mathrm{Hg}$ and $\mathrm{Cd}-\mathrm{Cr}$ ) and significant correlation within metals (viz. $\mathrm{Fe}-\mathrm{Cr}, \mathrm{Fe}-\mathrm{Cd}$ and $\mathrm{Cd}-\mathrm{Hg}$ ) in the channel sediments may reflect identical distribution/behavior of metals during their transport in channel system, or they may have originated from the common external source. From this, it can be inferred that these heavy metals enter into the channel system through the industrial discharge and their subsequent accumulation leads to elevated metal concentrations in channel sediments (Gupta et al. 2008).

Factor loading of the surface sediments shows (Table 12) that two factors F1 and F2 account for cumulative variance
Table 11 Pearson's correlation matrix for analyzed variables in sediment samples

\begin{tabular}{lllllllllll}
\hline Variables & $\mathrm{PH}$ & $\mathrm{EC}$ & $\mathrm{OC}$ & $\mathrm{Pb}$ & $\mathrm{Cd}$ & $\mathrm{Cr}$ & $\mathrm{Fe}$ & $\mathrm{Cu}$ & $\mathrm{Ni}$ & $\mathrm{Hg}$ \\
\hline $\mathrm{pH}$ & $\mathbf{1}$ & & & & & & & & \\
$\mathrm{EC}$ & 0.574 & $\mathbf{1}$ & & & & & & & \\
$\mathrm{OC}$ & -0.437 & -0.184 & $\mathbf{1}$ & & & & & & & \\
$\mathrm{Pb}$ & $\mathbf{0 . 9 4 0}$ & 0.724 & -0.241 & $\mathbf{1}$ & & & & & & \\
$\mathrm{Cd}$ & 0.534 & $\mathbf{0 . 9 6 9}$ & -0.257 & 0.674 & $\mathbf{1}$ & & & & & \\
$\mathrm{Cr}$ & 0.463 & $\mathbf{0 . 9 1 0}$ & -0.435 & 0.544 & $\mathbf{0 . 9 5 3}$ & $\mathbf{1}$ & & & & \\
$\mathrm{Fe}$ & -0.042 & $\mathbf{0 . 7 5 8}$ & 0.105 & 0.166 & $\mathbf{0 . 7 6 3}$ & $\mathbf{0 . 7 6 8}$ & $\mathbf{1}$ & & & \\
$\mathrm{Cu}$ & 0.622 & $\mathbf{0 . 7 6 6}$ & -0.583 & 0.571 & $\mathbf{0 . 8 3 5}$ & $\mathbf{0 . 9 0 2}$ & 0.501 & $\mathbf{1}$ & & \\
$\mathrm{Ni}$ & 0.574 & 0.443 & -0.640 & 0.399 & 0.525 & 0.654 & 0.224 & $\mathbf{0 . 8 9 6}$ & $\mathbf{1}$ & \\
$\mathrm{Hg}$ & $\mathbf{0 . 9 3 8}$ & $\mathbf{0 . 7 6 8}$ & -0.428 & $\mathbf{0 . 9 2 4}$ & $\mathbf{0 . 7 3 6}$ & 0.657 & 0.185 & $\mathbf{0 . 7 5 6}$ & 0.591 & $\mathbf{1}$ \\
\hline
\end{tabular}

Values in bold are different from 0 with a significance level alpha $=0.05$ 
Table 12 Factor loading matrix (after varimax rotation), eigenvalues and variances for sediment samples

\begin{tabular}{lrr}
\hline Variables & \multicolumn{1}{l}{ F1 } & \multicolumn{1}{l}{ F2 } \\
\hline $\mathrm{pH}$ & $\mathbf{0 . 7 8 0}$ & 0.294 \\
$\mathrm{EC}$ & $\mathbf{0 . 8 7 6}$ & -0.444 \\
$\mathrm{OC}$ & -0.560 & $-\mathbf{0 . 7 0 7}$ \\
$\mathrm{Pb}$ & $\mathbf{0 . 7 7 8}$ & -0.005 \\
$\mathrm{Cd}$ & $\mathbf{0 . 8 9 9}$ & -0.398 \\
$\mathrm{Cr}$ & $\mathbf{0 . 9 1 4}$ & -0.269 \\
$\mathrm{Fe}$ & 0.492 & $-\mathbf{0 . 7 4 3}$ \\
$\mathrm{Cu}$ & $\mathbf{0 . 9 3 7}$ & 0.042 \\
$\mathrm{Ni}$ & $\mathbf{0 . 7 3 0}$ & 0.283 \\
$\mathrm{Hg}$ & $\mathbf{0 . 8 8 9}$ & 0.106 \\
Eigenvalue & 6.695 & 2.160 \\
Variability (\%) & 60.864 & 19.634 \\
Cumulative (\%) & 60.864 & 80.498 \\
\hline
\end{tabular}

Values in bold correspond to each variable to the factor for which the squared cosine is the largest

of $80.498 \%$ (eigenvalue $>1$ ). F1 covers $60.864 \%$ of the total variance and explains strong positive loading for $\mathrm{pH}, \mathrm{EC}$, $\mathrm{Pb}, \mathrm{Cd}, \mathrm{Cr}, \mathrm{Cu}, \mathrm{Ni}$ and $\mathrm{Hg}$, indicating various assimilated contaminants derived from industrial and urban waste/wastewater discharge. The second factor F2 explains $19.634 \%$ of the total variance, includes strong negative loading for $\mathrm{OC}$ and $\mathrm{Fe}$ and can be corresponded with the geological process and background lithogenic factors. Therefore, it can be concluded that the source of heavy metals in channel sediments is majorly derived from industrial contamination, with a very minor contribution of $\mathrm{Fe}$ from geogenic sources (Gupta et al. 2010a).

\section{Conclusion}

In conclusion, this study clearly infers that the cause of heavy metal pollution in water and sediments of the monitored stream is mainly due to the industrial discharge and anthropogenic activities along the channel. The measured values of most of the water parameters and heavy metals decrease from the middle section (Site 1) to downstream stretches (Site 8) of the channel with few exceptions. Clear seasonal variation is shown by water parameters and heavy metals indicating higher concentrations in summer and lower values in the rainy season. The concentrations of $\mathrm{Pb}$, $\mathrm{Hg}$ and $\mathrm{Fe}$ in the stream water exceed the IS standards, while concentrations of most of the studied metals in channel sediments (except $\mathrm{Cu}$ and $\mathrm{Ni}$ ) are higher than the recommended SQGs. Metal pollution indices and multivariate statistical analysis are used to assess the variations and source of pollution in the study area, which infers that industrial discharge is majorly responsible for the spatial variability of water parameters and heavy metal concentrations in the study area. The results of various pollution indices clearly suggest that the degree of metal contamination in channel water and sediment is in alarming stage with very high ecological risk factor, which may pose serious threat to the ecological health of the study area. This situation seeks an immediate attention. There is also need for long-term investigation on contamination load in channel water-sediment and to develop a proper management strategy with an effective treatment scheme to reduce the potential threat and sustain the ecological integrity.

Acknowledgements The authors are grateful to the HOD, Department of Chemistry, National Institute of Technology, Durgapur, for supporting with infrastructure. Our sincere thanks are also due to all reviewers and editors of this manuscript for their valuable comments and suggestions.

Open Access This article is distributed under the terms of the Creative Commons Attribution 4.0 International License (http://creativeco mmons.org/licenses/by/4.0/), which permits unrestricted use, distribution, and reproduction in any medium, provided you give appropriate credit to the original author(s) and the source, provide a link to the Creative Commons license, and indicate if changes were made.

\section{References}

Abrahim GMS, Parker RJ (2008) Assessment of heavy metal enrichment factors and the degree of contamination in marine sediments from Tamaki Estuary, Auckland, New Zealand. Environ Monit Assess 136:227-238

Adams G, Randall A, Byung J (1997) Effect of ozonation on the biodegradability of substituted phenols. Water Res 31:2655-2663

Backman B, Bodis D, Lahermo P, Rajpant S, Tarvainen T (1997) Application of ground water contamination index in Finland and Slovakia. Environ Geol 36:55-64

Banerjee S, Kumar A, Maiti SK, Chowdhury A (2016) A Seasonal variation in heavy metal contaminations in water and sediments of Jamshedpur stretch of Subarnarekha river India. Environ Earth Sci 75:265

Barman SC, Lal MM (1994) Accumulation of heavy metals (Zn, Cu, $\mathrm{Cd}$ and $\mathrm{Pb}$ ) in soils and cultivated vegetables and weeds grown in industrially polluted fields. J Environ Biol 15:107-115

Barman SC, Sahu RK, Bhargava SK, Chatterjee C (2000) Distribution of heavy metals in wheat, mustard, and weed grown in fields irrigated with industrial effluents. Bull Environ Contam Toxicol 64:489-496

Blinova I, Bityukova L, Kasemets K, Ivaska A, Käkinena A, Kurvet I, Bondarenkoa O, Kanarbika L, Sihtmäea M, Aruojaa V, Schvede H, Kahrua A (2012) Environmental hazard of oil shale combustion fly ash. J Hazard Mater 229-230:192-200

Chung SY, Venkatramanan S, Park N, Ramkumar T, Sujitha SB, Jonathan MP (2016) Evaluation of physico-chemical parameters in water and total heavy metals in sediments at Nakdong River Basin, Korea. Environ Earth Sci 75(1):1-12

Edet AE, Offiong OE (2002) Evaluation of water quality pollution indices for heavy metal contamination monitoring. A study case from 
Akpabuyo-Odukpani area, Lower Cross River Basin (southeastern Nigeria). GeoJournal 57:295-304

Gao H, Bai J, Xiao R, Liu P, Jiang W, Wang J (2013) Levels, sources and risk assessment of trace elements in wetland soils of a typical shallow freshwater lake, China. Stoch Environ Res Risk Assess 27:275-284

Gupta S, Nayek S, Saha RN, Satpati S (2008) Assessment of heavy metal accumulation in macrophyte, agricultural soil, and crop plants adjacent to discharge zone of sponge iron factory. Environ Geol 55:731-739

Gupta S, Nayek S, Saha RN (2010a) Temporal changes and depth wise variations in pit pond hydrochemistry contaminated with industrial effluents with special emphasis on metal distribution in water-sediment system. J Hazard Mater 183:125-131

Gupta S, Satpati S, Nayek S, Garai D (2010b) Effect of wastewater irrigation on vegetables in relation to bioaccumulation of heavy metals and biochemical changes. Environ Monit Assess 165:169-177

Gupta S, Satpati S, Saha RN, Nayek S (2013) Assessment of spatial and temporal variation of pollutants along a natural channel receiving industrial wastewater. Int J Environ Eng 5(1):52-69

Hakanson L (1980) Ecological risk index for aquatic pollution control. A sedimentological approach. Water Res 14:975-1001

Hejabi AT, Basavarajappa HT, Karbassi AR, Monavari SM (2011) Heavy metal pollution in water and sediments in the Kabini River, Karnataka, India. Environ Monit Assess 182:1-13

Igwe JC, Abia AA (2003) Maize cob and Husk as adsorbents for removal of $\mathrm{Cd}, \mathrm{Pb}$ and $\mathrm{Zn}$ ions from waste water. Phys Sci 2:210-215

IS 2490 Part I (1981) Tolerance limits for industrial effluents discharged into inland surface waters. Part I. General Limits, Bureau of Indian Standards

Jain CK, Singhal DC, Sharma MK (2005) Metal pollution assessment of sediment and water in the river Hindon, India. Environ Monit Assess 105:193-207

James OO, Nwaeze K, Mesagan E, Agbojo M, Saka KL, Olabanji DJ (2013) Concentration of heavy metals in five pharmaceutical effluents in Ogun State, Nigeria. Bull Environ Pharmacol Life Sci 2(8):84-90

Kaushik A, Kansal A, Meena S, Kumari S, Kaushik CP (2009) Heavy metal contamination of river Yamuna, Haryana, India: assessment by metal enrichment factor of the sediments. J Hazard Mater 164:265-270

Kisku GC, Barman SC, Bhargava SK (2000) Contamination of soil and plants with potentially toxic elements irrigated with mixed industrial effluent and its impact on environment. Water Air Soil Pollut 120:121-127

Kisku GC, Pandey P, Negi MPS, Misra V (2011) Uptake and accumulation of potentially toxic metals $(\mathrm{Zn}, \mathrm{Cu}$ and $\mathrm{Pb}$ ) in soils and plants of Durgapur industrial belt. J Environ Biol 32:831-838

Kumar A, Maiti SK (2015) Assessment of potentially toxic heavy metal contamination in agricultural fields, sediment, and water from an abandoned chromite-asbestos mine waste of Roro hill, Chaibasa, India. Environ Earth Sci 74(3):2617-2633

Lara-Martín PA, Renfro AA, Cochran JK, Brownawell BJ (2015) Geochronologies of pharmaceuticals in a sewage-impacted estuarine urban setting (Jamaica Bay, New York). Environ Sci Technol 49:5948-5955

Lee CL, Fang MD, Hsieh MT (1998) Characterization and distribution of metals in surficial sediments in southwestern Taiwan. Mar Pollut Bull 36:464-471

Lenore SC, Arnold EG, Andrew DE (eds) (1998) Standard methods for the examination of water and wastewater/prepared and published jointly by American Public Health Association, American
Water Works Association, Water Environment Federation, 20th edn. American Public Health Association, Washington, DC

Liu C, Xu J, Zhang P, Dai M (2009) Heavy metals in the surface sediments in Lanzhou Reach of Yellow River, China. Bull Environ Contam Toxicol 82(1):26-30

Loska K, Wiechuya D (2003) Application of principle component analysis for the estimation of source of heavy metal contamination in surface sediments from the Rybnik Reservoir. Chemosphere 51:723-733

Lu S, Wang Y, Teng Y, Yu X (2015) Heavy metal pollution and ecological risk assessment of the paddy soils near a zinc-lead mining area in Hunan. Environ Monit Assess 187:627

MacDonald DD, Ingersoll C, Berger T (2000) Development and evaluation of consensus-based sediment quality guidelines for freshwater ecosystems. Arch Environ Contam Toxicol 39:20-31

Muller G (1981) The heavy metal pollution of the sediments of Neckars and its tributary: a stocktaking. Chem Zeit 105:157-164

Nayek S, Gupta S, Saha RN (2013) Heavy metal distribution and chemical fractionation in water, suspended solids and bed sediments of industrial discharge channel: an implication to ecological risk. Res J Chem Environ 17(6):26-33

Nyamangara J, Munotengwa S, Nyamugafata P, Nyamadzawo G (2007) The effect of hydroxide solutions on the structural stability and saturated hydraulic conductivity of four tropical soils. S Afr J Plant Soil 24(1):1-7

Rai PK (2009) Heavy metals in water, sediments and wetland plants in an aquatic ecosystem of tropical industrial region, India. Environ Monit Assess 158:433-457

Rai PK (2010) Seasonal monitoring of heavy metals and physicochemical characteristics in a lentic ecosystem of subtropical industrial region, India. Environ Monit Assess 165:407-433

Raju KV, Somashekar RK, Prakash KL (2012) Heavy metal status of sediment in river Cauvery, Karnataka. Environ Monit Assess 184:361-373

Ridgway J, Shimmield G (2002) Estuaries as repositories of historical contamination and their impact on shelf seas. Estuar Coast Shelf Sci 55:903-928

Salati S, Moore F (2010) Assessment of heavy metal concentration in the Khoshk River water and sediment, Shiraz, Southwest Iran. Environ Monit Assess 164:677-689

Schellmann W (1986) A new definition of laterite. In: Banerji PK (ed) Lateritisation processesm, IGCP-127. Geological Survey of India, vol 120, Memoir, New Delhi, pp 11-17

Shah BA, Shah AV, Mistry CB, Navik AJ (2012) Assessment of heavy metals in sediments near Hazira industrial zone at Tapti River estuary, Surat, India. Environ Earth Sci 69:2365-2376

Shakeri A, Shakeri R, Mehrabi B (2016) Contamination, toxicity and risk assessment of heavy metals and metalloids in sediments of ShahidRajaie Dam, Sefidrood and Shirinrood Rivers, Iran. Environ Earth Sci 75:679

Sin SN, Chua H, Lo W, Ng LM (2001) Assessment of heavy metal cations in sediments of ShingMun River, Hong Kong. Environ Int 26(2001):297-301

Sun Y, Zhou Q, Xie X, Liu R (2010) Spatial, sources and risk assessment of heavy metal contamination of urban soils in typical regions of Shenyang, China. J Hazard Mater 174:455-462

Sundaray SK, Nayak BB, Kanungo TK, Bhatta D (2012) Dynamics and quantification of dissolved heavy metals in the Mahanadi river estuarine system, India. Environ Monit Assess 184:1157-1179

Suthar S, Nema AK, Chabukdhara M, Gupta SK (2009) Assessment of metals in water and sediments of Hindon River, India: impact of industrial and urban discharges. J Hazard Mater 171:1088-1095

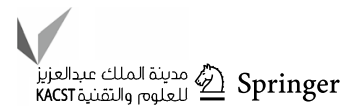


Sutherland RA (2000) Bed sediment-associated trace metals in an urban stream, Oahu, Hawaii. Environ Geol 39:611-627

Tomlison L, Wilson G, Harris R, Jeffrey DW (1980) Problems in the assessments of heavy metal levels in estuaries and formation of pollution index. Helgol Meeresun 33:566-575

USEPA, Method 3051a (2007) Microwave Assisted acid dissolution of sediments, sludges, soils, and oils, revision 1. United States Environmental Protection Agency, Washington, DC

Wakawa RJ, Uzairu A, Kagbu JA, Balarabe ML (2010) Seasonal variation assessment of impact of industrial effluents on physicochemical parameters of surface water of River Challawa, Kano, Nigeria. Toxicological \& Environmental Chemistry 92(1):27-38
Walkley A, Black IA (1934) An examination of Degtjareff method for determining soil organic matter and a proposed modification of the chromic acid titration method. Soil Sci 37:29-37

Wang W, Wang A, Chen L, Leu Y, Sun R (2002) Effects of pH on survival, phosphorus concentration, Adenylate Energy Charge and $\mathrm{Na}^{+}-\mathrm{K}^{+}$ATPase activities of Penaeus chinensis Osbeck Juveniles. Aquat Toxicol 60:75-83

Publisher's Note Springer Nature remains neutral with regard to jurisdictional claims in published maps and institutional affiliations. 